\title{
Modelling Barriers to the Adoption of Industrial Sustainability Measures
}

\author{
Trianni Andrea ${ }^{a}$, Cagno Enrico $^{a}$, Neri Alessandra ${ }^{*}$ \\ ${ }^{a}$ Department of Management Economics and Industrial Engineering, Politecnico di Milano, 20133 Piazza Leonardo da \\ Vinci 32, Milan, Italy \\ ${ }^{*}$ Corresponding author Tel.: +3902 23994095 e-mail address: alessandra.neri@polimi.it
}

Please cite as:

\author{
Trianni, A., Cagno, E., Neri, A. (2017). Modelling Barriers to the Adoption of Industrial \\ Sustainability Measures. Journal of Cleaner Production, 168, 1482-1504. \\ doi:10.1016/j.jclepro.2017.07.244.
}

\begin{abstract}
Sustainability is constantly gaining relevance among industrial decision makers, policy makers and scholars. In order to be sustainable, firms need to implement industrial sustainability measures, however there are many barriers to doing this. This work is based on a review of literature on barriers to the areas of occupational health and safety, eco efficiency, energy efficiency and to sustainability and contributes to industrial sustainability research by presenting a novel, integrated theoretical model of barriers to implementation of sustainability measures. The model encompasses previous literature review contributions and is intended to characterize and evaluate barriers to the adoption of industrial sustainability measures in all its areas. We have conducted a preliminary validation of the model investigating eight northern Italian manufacturing firms, looking at its ability to represent barriers to sustainability, usefulness and ease of use. We conducted semi-structured interviews to people responsible of the different areas of industrial sustainability, complemented by questionnaires and secondary materials. Results show a positive overall judgment of the model by all the interviewees. Moreover, the model was able to be applied to issues deriving from different perspectives and different areas of industrial sustainability. The findings can help firms and policy makers overcome barriers and they also provide insight into the different perspectives on the adoption of industrial sustainability measures than can be used to promote their adoption.
\end{abstract}

Keywords: Industrial Sustainability, Barriers, Measures, Energy efficiency, Eco efficiency, Occupational Health and Safety

\section{Introduction}

In recent years, the interest of policy-makers and industrial decision-makers in the sustainability of industrial activities has dramatically grown. The industrial sector is a domain in which there is real need to improve sustainability (Rademaekers et al., 2011): current modes of production are unsustainable and substantial technological, managerial, organizational and behavioral changes are required to make them more sustainable (Blok et al., 2015).

The Triple Bottom Line model (TBL) proposed by Elkington (1998) identifies sustainability as the intersection of three different pillars, namely economic, environmental and social. In the industrial context we can refer to corporate sustainability (CS), industrial sustainability (IS) and manufacturing sustainability (MS). CS usually relates to the strategic level (Lozano et al., 2015) and MS to the production system level (Garetti and Taisch, 2012), however IS relates to the industrial plant level. Indeed, IS accounts for all the actions that are referred to production plant (and not just the production 
line), i.e. requiring actions at the levels of material, product, process, plant and systems of production (Tonelli et al., 2013), as well as integration into normal operations (Evans et al., 2009), and it has been considered as the research domain of the present study. IS has been often identified in literature with the areas of occupational health and safety (OHS) (Pagell and Gobeli, 2009), and eco efficiency (EE) (Gimenez et al., 2012), with a growing relevance of energy efficiency (EnEff) issue within EE (Pehlken et al., 2015). OHS and EnEff can be identified using the TBL model as the intersections of social and economic pillars, and environmental and economic pillars respectively.

To improve their sustainability, firms have to implement measures in all IS areas. Although there is good evidence that such measures are effective and have a positive impact on firms' performance, e.g. (Fleiter et al., 2012a) for EnEff, (Hami et al., 2015) for sustainable practices, (Tompa et al., 2006) for OHS, many firms still struggle to implement them. OHS continues to be one of the major challenges for companies and policy-makers (Cagno et al., 2016), and there is general recognition that "the need to improve working conditions is a collective concern, prompted by both humanitarian and economic considerations" (Eurostat, 2016). The situation is also quite serious in relation to EE: industrial production is one of the biggest consumers of resources and one of the largest sources of waste (Eurostat, 2016), however adoption of measures has been very slow and more and faster actions are needed (Vermeulen and Witjes, 2016). Sustainability measures have been shown to have positive effects on economic and financial performance (Ambec and Lanoie, 2008), and it costs surprisingly little to implement cost-effective EnEff measures in firms (Fleiter et al., 2012a). However, less than $50 \%$ of manufacturing firms have adopted such measures due mainly to the long payback times and high costs (Anderson and Newell, 2004). There is often more emphasis on the economic impact of sustainability measures than on the social or environmental one. Authors show trade-offs (Salzmann et al., 2005) both between economic and environmental goals and between economic and social ones (Beckmann et al., 2014; Haffar and Searcy, 2017), and most firms will prioritize financial goals (Fennema, 2000), particularly in the short term (Van Der Byl and Slawinski, 2015). However, pursuing only economic goals is not enough to deliver long-term sustainability (Dyllick and Hockerts, 2002). Nevertheless it has been shown that implementing measures able to improve social and/or environmental performances can also have significant economic benefits (Henri and Journeault, 2009; Tanzil and Beloff, 2006).

This gap is due to the presence of barriers, so that sustainability measures are perceived as burdensome or unprofitable, e.g. (Cherniack and Lahiri, 2010) for OHS, (Vieira and Amaral, 2015) for EE, (Walsh and Thornley, 2012) for EnEff, or requiring too much organizational changes, e.g. (Smith and Carayon, 2009) for OHS, (Martín-Peña et al., 2014) for EE, (Liu et al., 2014) for EnEff. Barriers to single different areas of IS have been largely discussed in literature, focusing on specific industrial sector, geographical areas or firm's dimensions, e.g. (Whysall et al., 2006) for OHS, (Zhang et al., 2009) for EE, (Venmans, 2014) for EnEff, but none of these contributions has offered a comprehensive overview on barriers to IS. Indeed, hitherto research on barriers to IS as we intended it has been quite limited. There have been some studies of CS, but they have either not used formal measures (Lozano, 2013), or were based on empirical case studies and lacked a theoretical underpinning (Paramanathan et al., 2004). Summing up, there is thus no single, comprehensive model of barriers to the implementation of industrial sustainability measures (ISMs). Such a model would be of considerable interest as it would underline possible interdependences among the different IS areas and highlight similarities and differences, developing an effective strategy for tackling barriers to implementation of ISMs.

The remainder of the paper is structured as follows: in Section 2, literature review is conducted; in Section 3 research methods used for the development of the research are reported; in Section 4, the new model is introduced; in Section 5, the procedure for the evaluation of the validity of the model is presented; in Section 6 the results obtained are reported. Lastly, discussion and conclusion are provided in Section 7, along with limitations of the study and possible further research. 


\section{Literature review}

We carried out a background analysis of IS and of the different IS areas, so to obtain an understanding of the barriers affecting them. We focused both on IS and on CS because the two concepts are often misled - being to some extent interconnected - . For this reason, despite our research is focused on IS, including also CS offers a larger and more detailed analysis of existing contributions. We searched for relevant literature by querying the international databases SCOPUS, Google Scholar and ISI Web of Knowldge and also used the snowball method. Regarding keywords, we use barrier and similar terms, e.g. obstacle, combined with the terms related to the different level and areas considered, i.e. $I S, C S, O H S, E E, E n E f f$. We limited our review to work published in the last 20 years. Following, for each area of IS the relevant contributions have been analyzed according to: $i$ ) how the barriers have been presented in the study, i.e. namely by examples of barriers (single ones or a list of them), classification or taxonomy; ii) type of study, i.e. theoretical, empirical, or both; iii) whether the barriers were identified as internal or external in origin; and iv) nature of barriers such as, e.g. economic, organization or information-related.

\subsection{Industrial Sustainability and Corporate Sustainability}

Our analysis of barriers to IS and CS raised some interesting issues. Firstly, research has already observed a dearth of research on barriers to IS (Paramanathan et al., 2004), and CS, e.g. (Chowdhury et al., 2015). Additionally, IS and CS are often confused with or treated as overlapping with Corporate Social Responsibility (Arevalo and Aravind, 2011; Frankental, 2001) or environmental sustainability (Lodhia, 2003; Setthasakko, 2009). Focusing on CS, that presents a more developed literature than IS, two main general barriers to the implementation of measures emerge: the lack of understanding of the concept of CS, e.g. (Belal and Owen, 2007) and the difficulty of implementing CS measures in an integrated fashion, e.g. (Dyllick and Hockerts, 2002) and (Van Marrewijk, 2003). More specific barriers have been identified, such as resistance to change, e.g. (De Paiva Duarte, 2015), culture, e.g. (Doppelt, 2003), lack of awareness/ knowledge, e.g. (Lo and Sheu, 2007), human barriers relating to both employees, e.g. (Maximiano, 2005), and management, e.g. (Collins et al., 2010), lack of written internal policy, e.g. (Naeem and Welford, 2009), lack of resources, e.g. (Maximiano, 2005), lack of information, e.g. (Doppelt, 2003) and cost. The importance of regulatory barriers has also been underlined, e.g. (Hossain et al., 2010).

Two contributions emerged as of particular interest from our review. Firstly, Lozano (2013) reviewed organizational systems analyzing how they are influenced by attitudes. Lozano noted that most companies having implemented sustainable practices did it mainly as a result of upper management initiatives, and that, hitherto, firms have been treated as black boxes, thus not accounting for subcultures and intra-organizational differences. Lozano provided a very interesting contribution regarding barriers faced by an organization, distinguishing between barriers at individual-level, group level and organization level. Secondly, Collins et al., (2010) empirically analysed barriers to implementation of specific CS measures, evaluating barriers to measures related to different areas of CS, i.e. environmental, social and economic. This research offers a valuable contribution for a first identification of differences among the areas.

\subsection{Occupational Health and Safety}

We analyzed 17 publications dealing with OHS, reported in Table 1.

Organization barriers emerged as an important category of barrier to the implementation of OHS measures. Among them we can find barriers related to organizational structure, lack of resources (time and staff), or to the prioritizing of other activities, such as production, e.g. (Cunningham and Sinclair, 2015). Barriers related to human factors are also important. These are barriers related to the management, in particular its approach towards OHS, and to staff who may adopt inappropriate 
behaviors or may not be involved in OHS initiatives, e.g. (Barbeau et al., 2004). Literature shows that lack of knowledge and competence represents a very important barrier, e.g. (EASHW, 2010) . Further, economic barriers, mainly related to cost, e.g. (Quinlan and Mayhew, 2000), and to technological barriers, e.g. (Smith and Carayon, 2009) may be relevant. Regulatory barriers may also be a hindering factor, either through over-bureaucracy, e.g. (Champoux and Brun, 2003), or inadequate legislation, e.g. (Masi et al., 2014). There is a smaller number of publications dealing with barriers related to lack of external support, such a lack of technical support or guidelines, e.g. (Masi and Cagno, 2015). For the complete picture of the literature review regarding OHS, please refer to Table 1.

\subsection{Eco efficiency}

We included in our analysis of EE literature some publications dealing with closely related concepts, (Glavič and Lukman, 2007; Van Berkel, 2007), e.g., cleaner production (WBCSD and UNEP, 1998) and green manufacturing (Manzan and Miyake, 2013). We analyzed 30 publications on EE, reported in Table 2.

Discussion over economic barriers is large, pointing out the relevance of, e.g. high cost of investments, lack of financial resources, overly long payback time and the implementation risks, e.g. (Murillo-Luna et al., 2011). Organization barriers included other priorities over EE, lack of resources and the internal structure of the firm, e.g. (Hillary, 2004). Lack of awareness within an organization can also act as a barrier, e.g. (Biondi et al., 1998). Both these factors may apply to an organization generally or to the workers or management specifically. Human-related barriers such as inappropriate staff behavior, e.g. (Matus et al., 2012), and low management commitment, e.g. (Studer et al., 2006) are also important. Information-related barriers, e.g. (Côté et al., 2006) and technology-related barriers such as technological risk or lock-in can occur, e.g. (Ministerie Van Vrom, 2004). Further, we can find regulatory barriers, such as legal requirements and legislation, e.g. (Moors et al., 2005). Moreover, lack of external market pressure to implement measures is deemed as a very important barrier, e.g. (Zilahy, 2004). The importance of external support has been also recognized, e.g. (Shi et al., 2008). For the complete picture of the literature review regarding EE, please refer to Table 2.

\subsection{Energy efficiency}

We analyzed 38 publications related to EnEff, reported in Table 3.

The economic barriers such as high initial cost, lack of capital, payback time and hidden costs have a serious impact on implementation of measures, e.g. (Harris et al., 2000). Organization barriers include other issues taking priority over EnEff measures, inertia and internal structural problems, e.g. (Rohdin and Thollander, 2006). Lack of awareness (general, worker-specific or managementspecific) is also an important barrier as is lack of competence/knowledge at all levels, e.g. (Cooremans, 2012). Human behavior can represent a barrier, e.g. (Hasanbeigi et al., 2010): indeed, workers can adopt an incorrect behaviour, e.g. (Nagesha and Balachandra, 2006), or there may be a lack of management support, e.g. (Blass et al., 2014). Information-related barriers are those relating to lack of information and the trustworthiness of sources, e.g. (Kostka et al., 2013). Regulatory barriers may include bureaucracy and policy inconsistency or distortion, e.g. (Weber, 1997). Technology-related barriers are important, e.g. (De Groot et al., 2001), as is lack of market demand or external pressure, e.g. (Venmans, 2014), and problems related to market dynamics, such as uncertainties about energy prices or price distortions, e.g. (Worrell and Price, 2001). Lastly, the importance of external support has been also recognized, e.g. (Cagno et al., 2013). Finally, two major taxonomies for barriers can be observed in most recent literature contributions. First Sorrell et al. (2010), revising (Sorrell et al., 2000), identified six main barriers as follows: Risk, Imperfect information, Hidden costs, Access to capital, Split incentives, and Bounded rationality. Then, Cagno et al. (2013) developed a theoretical 
model of barriers to industrial energy efficiency based on an industrial decision- making empirical perspective, identifying the following categories, namely: Technology -related barriers, Information barriers, Economic, Behavioral, Organizational, Barriers related to competences, Awareness. A broad set of empirical studies based on those taxonomies can be found, e.g. (Schleich and Gruber, 2008) for the former, (Catarino et al., 2015) for the latter. For the complete picture of the literature review regarding EnEff, please refer to Table 3.

\subsection{Emerging gaps}

Some gaps were identified during the literature review:

- Authors have investigated barriers to IS and CS as a whole, nevertheless they had underlined difficulties in the integration of all the areas;

- The frameworks and models used in research on barriers to IS and CS are less structured than those applied to specific IS areas;

- To date research has evaluated barriers to IS by considering one area of IS at a time, rather than taking a holistic perspective and thus has failed to take account of possible interdependencies. Indeed, theoretical studies, e.g. (Hasle and Limborg, 2006) for OHS, (Silva Lopes et al., 2013) for EE, (Cagno et al., 2013) for EnEff, and empirical studies, e.g. (Mellor et al., 2011) for OHS, (Dobes, 2013) for EE, (Schleich, 2009) for EnEff, focusing on specific industrial sectors, e.g. (Whysall et al., 2006) for OHS, (Chan, 2008) for EE, (Okazaki and Yamaguchi, 2011) for EnEff, on specific geographical areas and countries, e.g. (EASHW, 2010) for OHS, (Murillo-Luna et al., 2011) for EE, (Venmans, 2014) for EnEff, or on small and medium-sized enterprises, e.g. (Lamm, 1999) for OHS, (Zhang et al., 2009) for EE, (Kostka et al., 2013) for EnEff, but, so far, no study has offered a comprehensive overview;

- previous research did not consider barriers to specific measure of IS as a whole, addressing them only at a general level. Collins et al. (2010) and Cagno and Trianni (2014) started evaluating barriers to specific measures, but they focused on a specific IS area, respectively the different areas of CS and EnEff without an integrated approach.

To conclude, an integrated approach accounting for potential similarities and differences among the measures in different areas is effectively required. 


\begin{tabular}{|c|c|c|c|c|c|c|c|c|c|c|c|c|}
\hline & \multirow{2}{*}{ Type } & \multirow[b]{2}{*}{ Theoretical } & \multirow[b]{2}{*}{ Empirical } & \multirow[b]{2}{*}{$\begin{array}{l}\text { Internal/ } \\
\text { External }\end{array}$} & \multicolumn{8}{|c|}{ Nature } \\
\hline & & & & & Management & Staff & Organisation & Knowledge & Support & Regulatory & Technology & Economic \\
\hline Rubenowitz, 1997 & E & & $x$ & & $x$ & $x$ & $x$ & & & & & \\
\hline Lamm, 1999 & E & & & & & $\mathrm{x}$ & $\mathrm{x}$ & $x(W)$ & $\mathrm{x}$ & & & $\mathrm{x}$ \\
\hline Quinlan and Mayhew, 2000 & E & & & & & & $\mathrm{x}$ & & & & & $\mathrm{x}$ \\
\hline Champoux and Brun, 2003 & C & & $x$ & & $x$ & $x$ & & & & $x$ & & $x$ \\
\hline Barbeau et al., 2004 & $E$ & & $x$ & & $x$ & $x$ & $x$ & & & & & \\
\hline Walker and Tait, 2004 & E & & $x$ & & & & $x$ & & & & & \\
\hline Hasle and Limborg, 2006 & E & $x$ & & & & & $x$ & & $x$ & $x$ & & $x$ \\
\hline Whysall et al., 2006 & E & & $x$ & & $x$ & $x$ & $x$ & & $x$ & & & \\
\hline Smith and Carayon, 2009 & C & $x$ & & & & $x$ & $x$ & & & & $x$ & \\
\hline Cherniack and Lahiri, 2010 & C & $x$ & $x$ & & & & $x$ & & & & & $x$ \\
\hline EASHW, 2010 & E & & $x$ & & & & $x$ & $x$ & $x$ & & & $x$ \\
\hline Hale et al., 2010 & E & & $x$ & & $x$ & $x$ & $x$ & & & & & \\
\hline Theberge and Neumann, 2010 & $E$ & & $x$ & & & & $x$ & & & & & \\
\hline Mellor et al., 2011 & C & & $x$ & & $x$ & $x$ & $x$ & & $x$ & & & \\
\hline Masi et al., 2014 & E & & $x$ & & $x$ & $x$ & $x$ & & & $x$ & & \\
\hline Cunningham and Sinclair, 2015 & E & & $x$ & & & & $x$ & $x$ & & & & \\
\hline Masi and Cagno, 2015 & C & $x$ & $x$ & $x$ & $x$ & $x$ & $x$ & & $x$ & $x$ & $x$ & \\
\hline
\end{tabular}

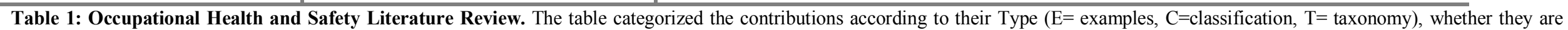

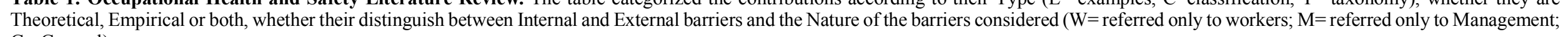
$\mathrm{G}=$ General) 


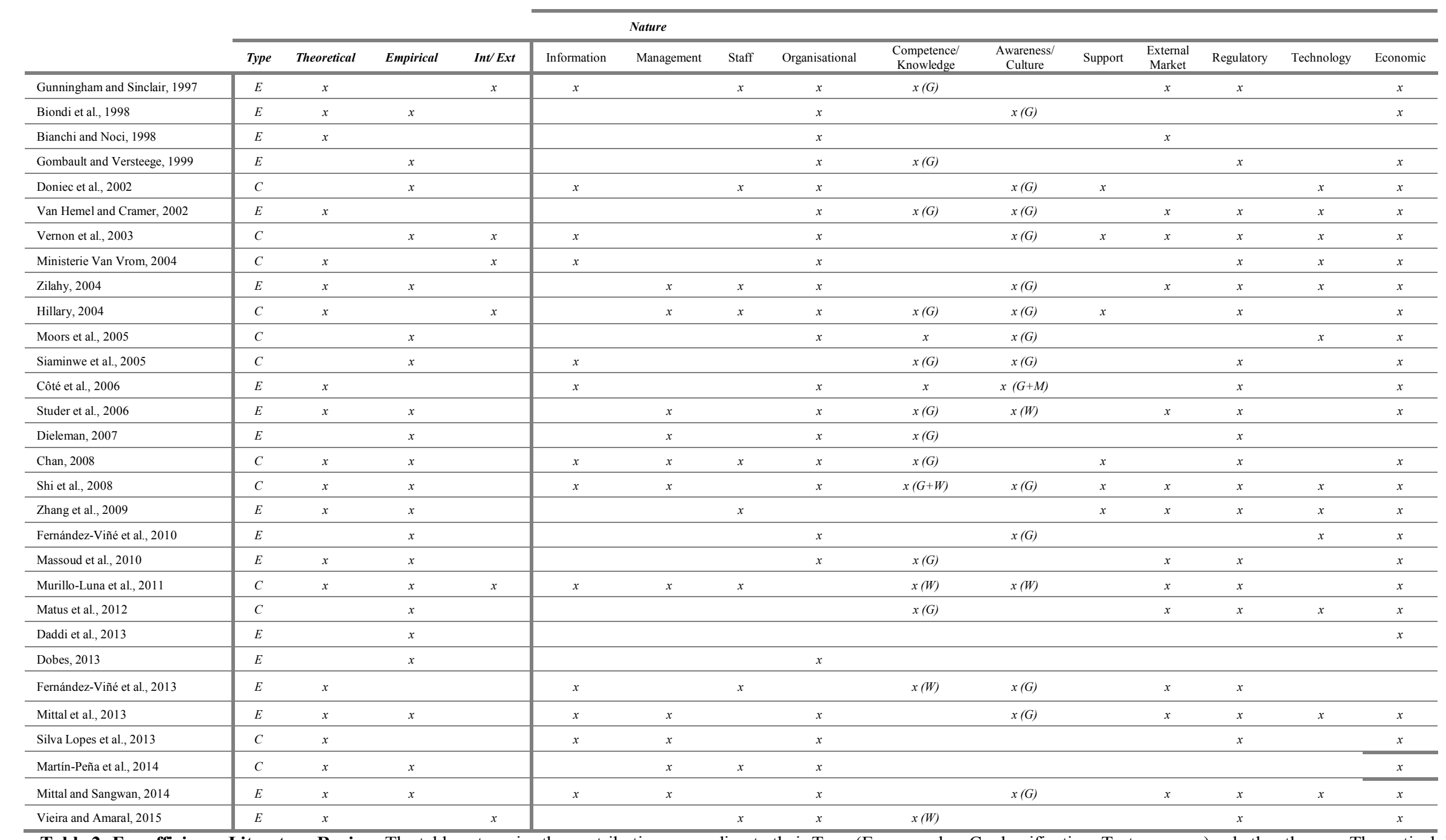

Table 2: Eco efficiency Literature Review. The table categories the contributions according to their Type (E= examples, $\mathrm{C}=$ classification, $\mathrm{T}=$ taxonomy), whether they are Theoretical, Empirical or both, whether they distinguish between Internal and the Nature of the barriers considered ( $\mathrm{W}=$ referred only to workers; $\mathrm{M}=$ referred only to Management; $\mathrm{G}=\mathrm{General}$ ) 


\begin{tabular}{|c|c|c|c|c|c|c|c|c|c|c|c|c|c|c|c|c|}
\hline & \multirow{2}{*}{ Type } & \multirow{2}{*}{ Theoretical } & \multirow{2}{*}{ Empirical } & \multirow{2}{*}{ Int/Ext } & \multicolumn{12}{|c|}{ Nature } \\
\hline & & & & & Information & Management & Staff & Organisation & $\begin{array}{c}\text { Competence/ } \\
\text { knowledge }\end{array}$ & Awareness & Behaviour & Support & $\begin{array}{c}\text { External } \\
\text { Market }\end{array}$ & Regulatory & Technology & Economic \\
\hline Weber, 1997 & C & $x$ & & & $x$ & & & $x$ & & $x(G)$ & & & $x$ & $x$ & & 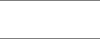 \\
\hline Reddy and Shrestha, 1998 & E & & $x$ & & $x$ & & & & & & & & $x$ & & & $x$ \\
\hline Harris et al., 2000 & C & $x$ & $x$ & & & & & & $x(G+W)$ & & & & & & & $x$ \\
\hline Sorrell et al., 2000 & $T$ & $x$ & & & $x$ & & & $x$ & & $x(G)$ & $x$ & & & & $x$ & $x$ \\
\hline De Groot et al., 2001 & C & $x$ & $x$ & & & & & $x$ & & & & & & & $x$ & $x$ \\
\hline Worrell and Price, 2001 & C & $x$ & & & $x$ & & & $x$ & $x(W)$ & & & & & & $x$ & $x$ \\
\hline Anderson and Newell, 2004 & $E$ & & $x$ & & $x$ & & & & & & & & & $x$ & & $x$ \\
\hline Sorrell et al., 2004 & $T$ & $x$ & & & $x$ & & & $x$ & & $x(G)$ & $x$ & & & & $x$ & $x$ \\
\hline Nagesha and Balachandra, 2006 & C & $x$ & $x$ & & $x$ & & & $x$ & & $x(G)$ & $x$ & & & $x$ & & $x$ \\
\hline Rohdin and Thollander, 2006 & E & $x$ & $x$ & & $x$ & & $x$ & $x$ & $x(G)$ & $x(W)$ & & & & & $x$ & $x$ \\
\hline Rohdin et al., 2007 & $E$ & $x$ & $x$ & & $x$ & $x$ & & $x$ & $x$ & $x(G+W)$ & & $x(G)$ & & & $x$ & $x$ \\
\hline Thollander et al., 2007 & E & $x$ & $x$ & & $x$ & $x$ & & $x$ & $x$ & $x(W)$ & & $x(G)$ & & & $x$ & $x$ \\
\hline Sardianou, 2008 & C & $x$ & $x$ & & & & & $x$ & $x(W+M)$ & & & & $x$ & & & $x$ \\
\hline Schleich and Gruber, 2008 & C & $x$ & $x$ & & $x$ & & & $x$ & & & & & 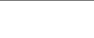 & & 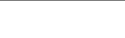 & $x$ \\
\hline Thollander and Ottosson, 2008 & E & $x$ & $x$ & & $x$ & $x$ & & $x$ & $x$ & $x(W)$ & & $x(G)$ & 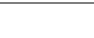 & & $x$ & $x$ \\
\hline Schleich, 2009 & C & & $x$ & & $x$ & & & $x$ & & & & & $x$ & & 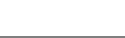 & 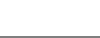 \\
\hline Hasanbeigi et al., 2010 & $E$ & & $x$ & & $x$ & $x$ & & $x$ & & & & & & $x$ & $x$ & $x$ \\
\hline Sorrell et al., 2010 & $T$ & $x$ & $x$ & & $x$ & & & $x$ & & $X(G)$ & $x$ & & $x$ & & $x$ & $x$ \\
\hline Okazaki and Yamaguchi, 2011 & C & & $x$ & & . & & & $x$ & $x(G)$ & & & & 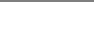 & $x$ & $x$ & $x$ \\
\hline Cooremans, 2012 & $E$ & $x$ & & & 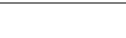 & $x$ & & $x$ & & & & & 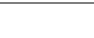 & 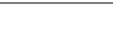 & . & $x$ \\
\hline Fleiter et al., 2012b & C & $x$ & $x$ & & 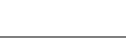 & & & $x$ & $x(G)$ & & 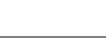 & & $x$ & & $x$ & $x$ \\
\hline Trianni and Cagno, 2012 & C & $x$ & $x$ & & & & & $x$ & & & $x$ & & $x$ & & & $x$ \\
\hline Walsh and Thornley, 2012 & $E$ & & $x$ & & 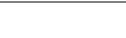 & & & $x$ & & & & & $x$ & $x$ & $x$ & $x$ \\
\hline Apeaning and Thollander, 2013 & E & $x$ & $x$ & & $x$ & $x$ & & $x$ & & $x(W)$ & & & & & $x$ & $x$ \\
\hline Cagno et al., 2013 & $T$ & $x$ & & $x$ & $x$ & & & $x$ & $x$ & $x$ & $x$ & $x$ & $x$ & $x$ & $x$ & $x$ \\
\hline Kostka et al., 2013 & C & $x$ & $x$ & $x$ & $x$ & & & $x$ & & & & & & & & $x$ \\
\hline Trianni et al., 2013a & $T$ & $x$ & $x$ & & $x$ & $x$ & & $x$ & $x(G)$ & $x$ & $x$ & & & & $x$ & $x$ \\
\hline Trianni et al., 2013b & $T$ & $x$ & $x$ & $x$ & $x$ & & & $x$ & $x$ & & $x$ & & & & $x$ & $x$ \\
\hline Trianni et al., 2013c & $T$ & $x$ & $x$ & $x$ & $x$ & & & $x$ & $x$ & $x$ & $x$ & & & & $x$ & $x$ \\
\hline Blass et al., 2014 & C & & $x$ & & & $x$ & & & & & & & & & & \\
\hline Brunke et al., 2014 & C & $x$ & $x$ & $x$ & & & & $x$ & $x$ & $x$ & $x$ & & $x$ & $x$ & & $x$ \\
\hline Cagno and Trianni, 2014 & C & $x$ & $x$ & $x$ & $x$ & & & $x$ & & $x$ & & & & & $x$ & $x$ \\
\hline Liu et al., 2014 & C & $x$ & $x$ & $x$ & & & & $x$ & $x$ & $x$ & & $x$ & & $x$ & & \\
\hline Venmans, 2014 & C & $x$ & $x$ & & $x$ & & & $x$ & & & & & & & $x$ & $x$ \\
\hline
\end{tabular}

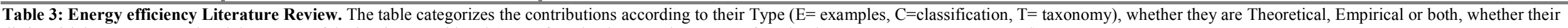

distinguish between Internal and the Nature of the barriers considered ( $\mathrm{W}=$ referred only to workers; $\mathrm{M}=$ referred only to Management; $\mathrm{G}=\mathrm{General}$ ) 


\section{Research methods}

Stemming from the literature review, the new model for barriers to IS has been developed. Indeed, after the analysis, the need for a new model was even more evident: contributions related to the different areas of IS presented several commonalities, such as the distinction between external and internal barriers in origin, and the further distinction into categories. We tried to create categories able to comprehend and represent all barriers. Barriers affecting the three IS areas present a considerable overlap; however, some differences are worth noting. We extended or modified some barrier's definition provided in literature, so to fit barriers referred in literature to one or two areas, to all the three areas. Stemming from the theoretical model proposed, we then developed a model for the empirical investigation, trying to understand how internal stakeholders perceive external barriers as internal ones. This has been done through the reconstruction of linkages with a logical approach supported, when available, by literature.

The validity of the model was assessed through case studies. We conducted a preliminary validation study in which we evaluated three performances: ability to represent, usefulness and ease of use. Each perfomance was evaluated using different questions. We investigated ability to represent considering the capability of the proposed model to represent the full set of barriers to IS, whether the barriers were sufficiently distinct and whether they had the same level of detail. We investigated usefulness by understanding, from the interviews, whether the model allowed pointing out barriers that to interviewees were not hitherto aware. Finally, the model would be useful if allows interviewees to better structure what they had already in mind, or for designing and implementation of measures, and whether the model would provide a valid and quick help for the identification of barriers. We assessed ease of use by understanding whether the model was easy to be used and if it was worth the effort. The reason for our choice to focus on northern Italian manufacturing firms was two-fold: first, the undoubted importance of the manufacturing sector to Europe generally and Italy in particular. Second, despite the primary role, there is still, indeed, ample room for improvement in all areas of IS (ILO, 2011; INAIL, 2014; Eurostat, 2016). Our company sample includes eight manufacturing firms differing in activity, size and turnover. Investigating a heterogeneous sample of companies provides evidence of the generalizability of an emerging theory (Eisenhardt, 1989). As case study research is judged on its theoretical generalizability rather than on its statistical generalizability (Hillebrand et al., 2001; Stuart et al., 2002), we decided that a sample of eight firms was adequate for validate the initial set of propositions, basing also on previous research (Eisenhardt, 1989; Pagell and Wu, 2009), according to which a set from 6 up to 10 cases would be a proper one. We chose to perform investigation with people in charge of EE, EnEff and OHS, so to collect the most appropriate information and data. We interviewed thirteen people in relevant leadership positions in eight firms, with details reported in Table 4.

\begin{tabular}{|c|c|c|c|c|c|}
\hline & ATECO & Sector & Employees & Turnover & Persons interviewed \\
\hline Company 1 & C 28.10 & $\begin{array}{l}\text { Manufacture of general - purpose } \\
\text { machinery }\end{array}$ & 370 & $50.000 \mathrm{k} €$ & $\begin{array}{l}\text { Health Safety and Environment Manager } 1 \\
\text { Health Safety and Environment Manager } 2 \\
\text { Maintenance Manager }\end{array}$ \\
\hline Company 2 & C 21 & $\begin{array}{c}\text { Manufacture of basic pharmaceutical } \\
\text { products }\end{array}$ & $\begin{array}{c}130 \\
\text { (in the plant) }\end{array}$ & $200.000 \mathrm{k} €$ & Health Safety and Environment Manager \\
\hline Company 3 & C 28.30 & $\begin{array}{l}\text { Manufacture of agricultural and forestry } \\
\text { machinery }\end{array}$ & 47 & $20.000 \mathrm{k} €$ & $\begin{array}{c}\text { OHS Manager } \\
\text { Energy and Environmental Manager }\end{array}$ \\
\hline Company 4 & C 20.15 & $\begin{array}{l}\text { Manufacture of fertilizers and nitrogen } \\
\text { compounds }\end{array}$ & 35 & $15.000 \mathrm{k} €$ & $\begin{array}{c}\text { OHS Manager } \\
\text { Quality Manager }\end{array}$ \\
\hline Company 5 & C 17.22 & $\begin{array}{l}\text { Manufacture of household and sanitary } \\
\text { goods }\end{array}$ & 250 & $75.000 \mathrm{k} €$ & $\begin{array}{l}\text { OHS Manager } \\
\text { Technical Director }\end{array}$ \\
\hline Company 6 & C 25.40 & Manufacture of weapons and ammunition & About 500 & $80.000 \mathrm{k} €$ & Health Safety and Environment Manager \\
\hline Company 7 & C 28.20 & $\begin{array}{l}\text { Manufacture of other general-purpose } \\
\text { machinery }\end{array}$ & 184 & $50.000 \mathrm{k} €$ & Health Safety and Environment Manager \\
\hline Company 8 & C 21.20 & Manufacture of biotech pharmaceuticals & 21 & $500 \mathrm{k} €$ & $\mathrm{CEO}$ \\
\hline
\end{tabular}

Table 4: Main information of the companies in the selected sample 


\section{Development of a new model for barriers to industrial sustainability measures}

Taking inspiration by previous literature, barriers have been reorganized into internal and external, as well as in categories, trying to comprehend and represent all barriers previously identified by scholars. The external barrier categories were: regulatory, support and market barriers and the internal barrier categories were: organization, management behavior, worker behavior, information, technology/service and economic barriers.

The model of barriers is represented in Figure 1 and detailed in Table 5. Origin, categories and barriers are presented, as well as a description of each barrier and references.

Figure 1: The model of barriers to industrial sustainability.

The arrows indicate different industrial sustainability measures. Measures pass through three different lenses, i.e. barriers related to the different areas of industrial sustainability, namely eco-efficiency, energy-efficiency and occupational health and safety (OHS), without any prioritization order. Passing through these lenses, measures can be stopped by barriers (solid vertical bars) related to the different areas. If they are stopped (dashed arrows), they are not able to reach the target, i.e. positively impact on industrial sustainability.

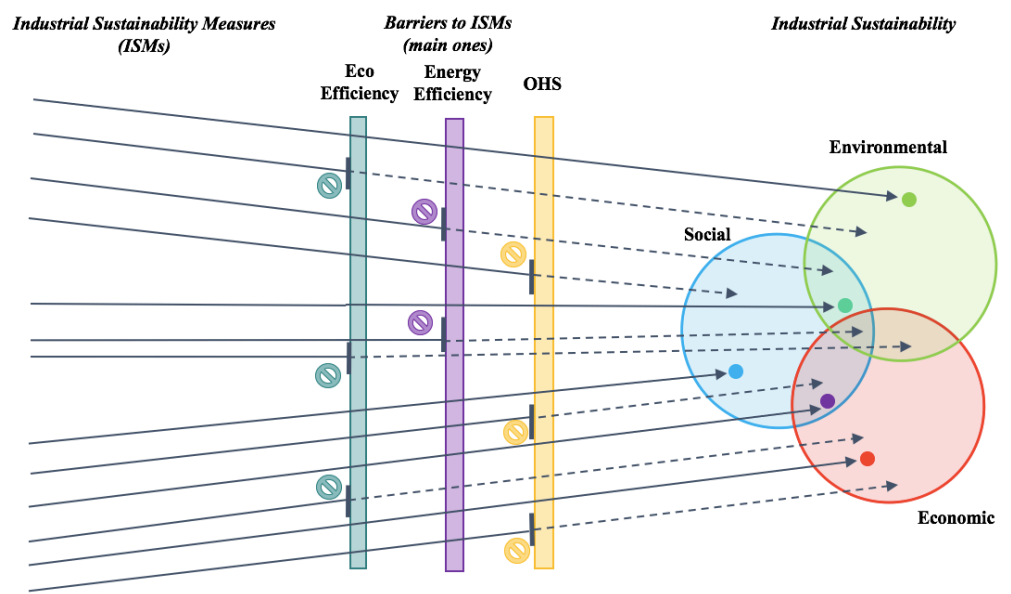

$\begin{array}{llll}\text { Origin } & \text { Category } & \text { Barrier } & \text { Definition } \\ \text { External } & \text { Regulatory } & \begin{array}{l}\text { Legal } \\ \text { requirements }\end{array} & \begin{array}{l}\text { Legal requirements are excessive } \\ \text { or not effective with respect to } \\ \text { the real needs of the company } \\ \text { related to sustainability }\end{array} \\ & & & \end{array}$

\section{Literature references}

OHS: Hasle and Limborg, 2006; Masi et al., 2014; Masi and Cagno, 2015

EE: Côté et al., 2006; Dieleman, 2007; Fernández-Viñé et al., 2013; Gombault and Versteege, 1999; Gunningham and Sinclair, 1997; Hillary, 2004; Massoud et al., 2010; Matus et al., 2012; Ministerie Van Vrom, 2004; Mittal et al., 2013; Mittal and Sangwan, 2014; Moors et al., 2005; Murillo-Luna et al., 2011; Shi et al., 2008; Silva Lopes et al., 2013; Studer et al., 2006; Van Hemel and Cramer, 2002; Vernon et al., 2003; Vieira and Amaral, 2015; Zilahy, 2004

EnEff: Hasanbeigi et al., 2010; Liu et al., 2014; Nagesha and Balachandra, 2006; Okazaki and Yamaguchi, 2011; Walsh and Thornley, 2012; Weber, 1997
Bureaucracy Excessive amount of paperwork necessary to be compliant with legal requirements, which is not tailored with respect to the capabilities of the company.

Lack of No economic incentives such as incentives tax exemptions and grants for the implementation of measures.

OHS: Champoux and Brun, 2003; Masi et al., 2014; Masi and Cagno, 2015

EE: Matus et al., 2012; Murillo-Luna et al., 2011

EnEff: Anderson and Newell, 2004; Sardianou, 2008

EE: Massoud et al., 2010; Shi et al., 2008; Studer et al., 2006

EnEff: De Groot et al., 2001; Hasanbeigi et al., 2010;

Nagesha and Balachandra, 2006; Okazaki and

Yamaguchi, 2011; Walsh and Thornley, 2012

Policy Taxes, subsides or other policy

EnEff: Cagno et al., 2013; Walsh and Thornley, 2012

distortion that discourage measure's implementation

Support Lack of $\quad$ Firm does not receive a technical
external support suitable to its needs 
technical

support

Lack of

consultancy

$\begin{array}{ll}\text { Market } & \begin{array}{l}\text { Customer not } \\ \text { ready /Lack of } \\ \text { demand }\end{array}\end{array}$

demand

Uncertainty of
future trend

future trend

Distortion of

price

Internal Organization Lack of time consultancy (from services, insurance companies, accounts, public authorities) that can help firm in the different phases of the decision making

Customers are not sensible to the issue thus not requiring a minimum level of performance e.g. not demanding green products/not demanding specific safety requirements

Without guidance on the future trend e.g. the prices of energy, natural resources or fines lower of sustainability, measures may be avoided

Prices do not reflect all the externalities (that can be related for example to environment or to social costs).

Firm has not enough time for the implementation of the measure
There is not an adequate

$\begin{array}{ll}\text { Lack of staff } & \begin{array}{l}\text { Firm has not enough staff for the } \\ \text { implementation of the measure }\end{array}\end{array}$

$\begin{array}{ll}\text { Lack of staff } & \text { Firm has not enough staff for the } \\ \text { implementation of the measure }\end{array}$

$\underline{2008}$

EnEff: Cagno et al., 2013; Trianni and Cagno, 2012

OHS: Hasle and Limborg, 2006; Masi and Cagno, 2015

EE: Chan, 2008; Hillary, 2004

EnEff: Trianni and Cagno, 2012

EE: Bianchi and Noci, 1998; Fernández-Viñé et al., 2013; Massoud et al., 2010; Mittal et al., 2013; Shi et al., 2008; Studer et al., 2006; Van Hemel and Cramer, 2002; Zhang et al., 2009; Zilahy, 2004

EnEff: Nagesha and Balachandra, 2006; Reddy and Shrestha, 1998; Venmans, 2014; Walsh and Thornley, 2012

EE: Mittal et al., 2013; Mittal and Sangwan, 2014;

Studer et al., 2006

EnEff: Brunke et al., 2014; Hasanbeigi et al., 2010; Nagesha and Balachandra, 2006; Sardianou, 2008; Schleich and Gruber, 2008

EE: Gunningham and Sinclair, 1997; Ministerie Van Vrom, 2004; Moors et al., 2005

EnEff: Cagno et al., 2013; Walsh and Thornley, 2012; Worrell and Price, 2001

OHS: Barbeau et al., 2004; Champoux and Brun, 2003; EASHW, 2010; Hasle and Limborg, 2006; Masi et al., 2014; Masi and Cagno, 2015; Whysall et al., 2006 EE: Biondi et al., 1998; Chan, 2008; Côté et al., 2006; Dieleman, 2007; Dobes, 2013; Fernández-Viñé et al., 2010; Gombault and Versteege, 1999; Hillary, 2004; Martín-Peña et al., 2014; Massoud et al., 2010; Matus et al., 2012; Mittal et al., 2013; Mittal and Sangwan, 2014; Studer et al., 2006; Van Hemel and Cramer, 2002; Vernon et al., 2003; Vieira and Amaral, 2015 EnEff: Apeaning and Thollander, 2013; Brunke et al., 2014; Fleiter et al., 2012b; Rohdin et al., 2007; Rohdin and Thollander, 2006; Schleich and Gruber, 2008; Thollander et al., 2007; Thollander and Ottosson, 2008 OHS: Champoux and Brun, 2003; Cunningham and Sinclair, 2015; EASHW, 2010; Hasle and Limborg, 2006; Masi et al., 2014; Mellor et al., 2011; Whysall et al., 2006

EE: Bianchi and Noci, 1998; Biondi et al., 1998; Chan, 2008; Côté et al., 2006; Dieleman, 2007; Dobes, 2013; Gunningham and Sinclair, 1997; Hillary, 2004; Matus et al., 2012; Ministerie Van Vrom, 2004; Mittal et al., 2013; Mittal and Sangwan, 2014; Studer et al., 2006; Vernon et al., 2003

EnEff: Kostka et al., 2013; Sardianou, 2008

Resistance to Organization can be against the change/Inertia change since it leads to a modification in ways of working and in habits

: Matus et al., 2012; Rubenowitz. 1997

EE: Dobes, 2013; Fernández-Viñé et al., 2010; Gunningham and Sinclair, 1997; Moors et al., 2005; Murillo-Luna et al., 2011; Shi et al., 2008; Silva Lopes et al., 2013; Studer et al., 2006; Vieira and Amaral, 2015 EnEff: Cagno et al., 2013; Nagesha and Balachandra, 2006; Sorrell et al., 2000; Thollander et al., 2007

Attitude/ Other The culture and the values of the priorities firm inhibit the implementation of the measures. Moreover, the decision making might be focus almost uniquely on core the business activity, thus focused mainly on productivity related measures.
OHS: Barbeau et al., 2004; Champoux and Brun, 2003; EASHW, 2010; Hasle and Limborg, 2006; Masi and Cagno, 2015; Quinlan and Mayhew, 2000; Whysall et al., 2006

EE: Doniec et al., 2002; Gombault and Versteege, 1999; Massoud et al., 2010; Murillo-Luna et al., 2011; Shi et al., 2008; Studer et al., 2006; Vernon et al., 2003 EnEff: Apeaning and Thollander, 2013; Brunke et al., 2014; De Groot et al., 2001; Fleiter et al., 2012b; Hasanbeigi et al., 2010; Okazaki and Yamaguchi, 2011; Rohdin et al., 2007; Rohdin and Thollander, 2006; Schleich, 2009; Schleich and Gruber, 2008; Thollander 
et al., 2007; Thollander and Ottosson, 2008; Venmans, 2014; Weber, 1997

Communication Lack of communication or the inadequacy of communication between management and workers or between the workers themselves

Workplace and Not taking into account the task workplace (analysis of the workplace, like hazard exposures) and the tasks (design, pace, repetition, pressure and psychosocial issues) during the implementation of a measure may have inhibitory consequences

Organizational The firm is a social system system
OHS: Masi and Cagno, 2015; Mellor et al., 2011

EE: Gunningham and Sinclair, 1997; Silva Lopes et al., 2013; Vieira and Amaral, 2015

EnEff: Walsh and Thornley, 2012

OHS: Rubenowitz, 1997; Smith and Caravon, 2009 influenced by goals, routine, organizational structure and dominated by the decision making. There are several factors related to the company's structure that can hinder measures.

$\begin{array}{lll}\begin{array}{l}\text { Management } \\ \text { behavior }\end{array} & \begin{array}{l}\text { Commitment/ } \\ \text { Awareness }\end{array} & \begin{array}{l}\text { Manager has no awareness and/or } \\ \text { commitment. }\end{array}\end{array}$

\author{
OHS: Champoux and Brun, 2003; Cherniack and Lahiri, \\ 2010; Hale et al., 2010; Hasle and Limborg, 2006; \\ Lamm, 1999; Masi and Cagno, 2015; Mellor et al., 2011; \\ Rubenowitz, 1997; Smith and Carayon, 2009
}

EE: Hillary, 2004; Martín-Peña et al., 2014; Moors et al., 2005; Murillo-Luna et al., 2011; Vieira and Amaral, 2015

EnEff: Apeaning and Thollander, 2013; Brunke et al., 2014; De Groot et al., 2001; Fleiter et al., 2012b; Hasanbeigi et al., 2010; Liu et al., 2014; Rohdin et al., 2007; Schleich, 2009; Schleich and Gruber, 2008; Sorrell et al., 2000; Thollander et al., 2007; Thollander and Ottosson, 2008; Venmans, 2014; Walsh and Thornley, 2012; Weber, 1997

OHS: Hale et al., 2010; Masi et al., 2014; Masi and Cagno, 2015; Mellor et al., 2011; Rubenowitz, 1997; Walker and Tait, 2004; Whysall et al., 2006

EE: Dieleman, 2007; Martín-Peña et al., 2014; Mittal et al., 2013; Mittal and Sangwan, 2014; Shi et al., 2008; Silva Lopes et al., 2013; Studer et al., 2006 EnEff: Blass et al., 2014; Brunke et al., 2014; Cagno et al., 2013; Liu et al., 2014; Sardianou, 2008; Schleich, 2009

$\begin{array}{ll}\begin{array}{l}\text { Workers } \\ \text { behaviour }\end{array} & \begin{array}{l}\text { Not trained/ } \\ \text { skilled }\end{array}\end{array}$

Expertise $\quad$ Manager lacks of adequate management skills with respect to the issue or have limited expertise. Lack of adequate skill or training of the personnel, with respect to a specific measure area, can hinder the implementation of measure.

OHS: Hale et al., 2010; Masi and Cagno, 2015

EE: Côté et al., 2006; Dieleman, 2007; Gombault and Versteege, 1999; Gunningham and Sinclair, 1997; Shi et al., 2008; Silva Lopes et al., 2013

EnEff: Sardianou, 2008

OHS: Lamm, 1999; Masi and Cagno, 2015; Smith and Carayon, 2009; Theberge and Neumann, 2010; Walker and Tait, 2004

EE: Chan, 2008; Côté et al., 2006; Dieleman, 2007; Fernández-Viñé et al., 2013; Gombault and Versteege, 1999; Gunningham and Sinclair, 1997; Hillary, 2004; Matus et al., 2012; Moors et al., 2005; Shi et al., 2008; Silva Lopes et al., 2013; Vieira and Amaral, 2015

EnEff: Apeaning and Thollander, 2013; Brunke et al., 2014; Liu et al., 2014; Rohdin et al., 2007; Rohdin and Thollander, 2006; Sardianou, 2008; Thollander and Ottosson, 2008; Venmans, 2014; Worrell and Price, 2001 OHS: Masi and Cagno, 2015; Rubenowitz, 1997; Smith and Carayon, 2009

EE: Fernández-Viñé et al., 2013; Martín-Peña et al., 2014; Silva Lopes et al., 2013; Studer et al., 2006; Zhang et al., 2009; Zilahy, 2004

EnEff: Apeaning and Thollander, 2013; Brunke et al., 2014; Cagno et al., 2013; Liu et al., 2014; Rohdin et al., 2007; Rohdin and Thollander, 2006; Sardianou, 2008; Thollander et al., 2007; Thollander and Ottosson, 2008; Venmans, 2014

Not involved Employees not involved are given a fair opportunity to take
OHS: Hale et al., 2010; Masi and Cagno, 2015; Mellor et al., 2011; Rubenowitz, 1997; Walker and Tait, 2004 
an active part in the decisionmaking and realization process.

Incorrect The adoption of wrong behaviors behaviour by the personnel can hinder the implementation of sustainability measures in case in which an active participation of the personnel is required

Information Lack of Lack of information or
information inadequacy of the information owned by the firm with reference to all the aspects related to measure implementation
EE: Silva Lopes et al., 2013

EnEff: Sardianou, 2008

OHS: Champoux and Brun, 2003; Masi et al., 2014; Masi and Cagno, 2015; Whysall et al., 2006
Trustworthiness Problems with trustworthiness of of information the information sources, the sources are not adequate.

Technology/ Lock in Service

$\begin{array}{lll}\text { Economic } & \begin{array}{l}\text { Limited access } \\ \text { to capital }\end{array} & \begin{array}{l}\text { Firm does not have sufficient } \\ \text { capital for the implementation }\end{array}\end{array}$

Solution is incompatible with the current status of the system.
OHS: Barbeau et al., 2004; Cherniack and Lahiri, 2010; Masi and Cagno, 2015; Walker and Tait, 2004

EE: Côté et al., 2006; Doniec et al., 2002; FernándezViñé et al., 2013; Gunningham and Sinclair, 1997; Ministerie Van Vrom, 2004; Mittal et al., 2013; Mittal and Sangwan, 2014; Murillo-Luna et al., 2011; Shi et al., 2008

EnEff: Anderson and Newell, 2004; Apeaning and Thollander, 2013; Brunke et al., 2014; Cagno et al., 2013; Hasanbeigi et al., 2010; Kostka et al., 2013; Okazaki and Yamaguchi, 2011; Reddy and Shrestha, 1998; Rohdin et al., 2007; Rohdin and Thollander, 2006; Sardianou, 2008; Schleich, 2009; Schleich and Gruber, 2008; Sorrell et al., 2000; Thollander et al., 2007; Thollander and Ottosson, 2008; Venmans, 2014; Weber, 1997; Worrell and Price, 2001

EnEff: Cagno et al., 2013; Rohdin and Thollander, 2006; Sardianou, 2008; Sorrell et al., 2000; Venmans, 2014; Worrell and Price, 2001

EE: Ministerie Van Vrom, 2004; Mittal et al., 2013; Mittal and Sangwan, 2014

EnEff: Apeaning and Thollander, 2013; Okazaki and Yamaguchi, 2011; Rohdin et al., 2007; Rohdin and Thollander, 2006; Sardianou, 2008; Thollander et al., 2007; Thollander and Ottosson, 2008; Venmans, 2014 OHS: Barbeau et al., 2004; Cherniack and Lahiri, 2010; EASHW, 2010; Hasle and Limborg, 2006; Masi et al., 2014; Masi and Cagno, 2015

EE: Biondi et al., 1998; Côté et al., 2006; Doniec et al., 2002; Gombault and Versteege, 1999; Gunningham and Sinclair, 1997; Matus et al., 2012; Moors et al., 2005; Shi et al., 2008; Siaminwe et al., 2005; Silva Lopes et al., 2013; Studer et al., 2006; Vernon et al., 2003; Vieira and Amaral, 2015; Zilahy, 2004

EnEff: Apeaning and Thollander, 2013; Brunke et al., 2014; Cagno et al., 2013; De Groot et al., 2001; Fleiter et al., 2012b; Hasanbeigi et al., 2010; Kostka et al., 2013; Nagesha and Balachandra, 2006; Okazaki and Yamaguchi, 2011; Rohdin et al., 2007; Rohdin and Thollander, 2006; Sardianou, 2008; Schleich, 2009; Schleich and Gruber, 2008; Sorrell et al., 2000; Thollander et al., 2007; Thollander and Ottosson, 2008; Trianni and Cagno, 2012; Venmans, 2014; Walsh and Thornley, 2012; Worrell and Price, 2001

\begin{tabular}{ll}
\hline Hidden costs & $\begin{array}{l}\text { Investment entails extra costs or } \\
\text { loss of benefits that are no } \\
\text { properly estimate in investments } \\
\text { analysis. }\end{array}$ \\
\hline Risk & $\begin{array}{l}\text { Risk related to the success of the } \\
\text { measures e.g. interruption of } \\
\text { production, losses in quality. }\end{array}$
\end{tabular}

EnEff: Brunke et al., 2014; Cagno et al., 2013; Kostka et al., 2013; Rohdin et al., 2007; Rohdin and Thollander, 2006; Sorrell et al., 2000

EE: Gunningham and Sinclair, 1997; Moors et al., 2005 EnEff: Apeaning and Thollander, 2013; Brunke et al., 2014; Cagno et al., 2013; De Groot et al., 2001; Fleiter et al., 2012b; Hasanbeigi et al., 2010; Okazaki and Yamaguchi, 2011; Rohdin et al., 2007; Rohdin and Thollander, 2006; Schleich, 2009; Sorrell et al., 2000; Thollander et al., 2007; Thollander and Ottosson, 2008; Venmans, 2014; Walsh and Thornley, 2012; Worrell and Price, 2001

Investment cost High investments costs prevent OHS: Champoux and Brun, 2003; Cherniack and Lahiri, 2010; Hasle and Limborg, 2006 firms from implementing sustainability measures.
EE: Chan, 2008; Daddi et al., 2013; Doniec et al., 2002; 


Martín-Peña et al., 2014; Massoud et al., 2010; Matus et
al., 2012; Ministerie Van Vrom, 2004; Mittal and
Sangwan, 2014; Murillo-Luna et al., 2011; Shi et al.,
2008; Silva Lopes et al., 2013; Studer et al., 2006;
Vernon et al., 2003; Vieira and Amaral, 2015; Zhang et
al., 2009; Zilahy, 2004
EnEff: Cagno et al., 2013; Fleiter et al., 2012b; Nagesha
and Balachandra, 2006; Reddy and Shrestha, 1998
OHS: Champoux and Brun, 2003; Cherniack and Lahiri,
2010
EE: Chan, 2008; Côté et al., 2006; Daddi et al., 2013;
Gunningham and Sinclair, 1997; Massoud et al., 2010;
Matus et al., 2012; Mittal et al., 2013; Mittal and
Sangwan, 2014; Shi et al., 2008; Siaminwe et al., 2005;
Silva Lopes et al., 2013; Vieira and Amaral, 2015;
Zilahy, 2004
EnEff: Fleiter et al., 2012b; Nagesha and Balachandra,
2006; Reddy and Shrestha, 1998; Sardianou, 2008;
Schleich, 2009; Schleich and Gruber, 2008; Sorrell et al.,
2000; Trianni and Cagno, 2012; Walsh and Thornley,
2012; Worrell and Price, 2001

\footnotetext{
Table 5: The new model for barriers to the adoption of Industrial Sustainability Measures. Categories are divided, according to their Origin, in Internal and External. For each barrier, definition and references are provided for each of the three areas on Industrial Sustainability. The main reference, on which the definition is based, is underlined.
}

This operation allowed us to point out several elements of novelty. First, we found that many barriers could also apply to areas other than those cited. For instance, lack of incentives is reported as a barrier to EE (Massoud et al., 2010) and EnEff (Walsh and Thornley, 2012), but not within OHS; however, lack of incentives for firms that would like to go beyond the legal requirements' targets can be perceived as a barrier. Policy distortion was identified as a barrier to EnEff (Walsh and Thornley, 2012) but not OHS and EE, but the existence of taxes and disincentive policies, discouraging the implementation of measures could be a barrier. Market-related barriers affecting EE (Fernández-Viñé et al., 2010) and EnEff (Venmans, 2014) were reported, but may also apply to OHS. Here, lack of demand may be seen as analogous to lack of a requirement for a certain level of safety, uncertainty about future trends could apply to fines and price distortion can result in an economic advantage deriving from not fulfilling the legal requirements. Workplace and task-related barriers to OHS (Smith and Carayon, 2009) may also be relevant to EE and EnEff, as EE and EnEff measures may affect the workplace or workers' tasks. Incorrect behavior of workers, identified as a barrier to OHS is also relevant to EE and EnEff because it may cause the failure of measures. Trustworthiness of information, identified as a barrier to EnEff (Worrell and Price, 2001) is also relevant to OHS and EE. Technological lock-in, identified for EE (Mittal and Sangwan, 2014) and EnEff (Okazaki and Yamaguchi, 2011), can represent a barrier also for OHS when the new technological solution is in contrast with the actual one. Economic barriers identified only for EnEff, i.e. hidden costs or for EE (Sorrell et al., 2000), i.e. risk, for EE (Moors et al., 2005) and EnEff (Fleiter et al., 2012b), can be relevant barrier also for the other areas, when the measures have costs not adequately identified or loss of benefits (e.g. production) not properly analyzed before the implementation.

After developing the theoretical framework, we adapted it for the empirical investigation. In fact, firms are only able to perceive internal barriers for what they really are; perception of external barriers is based on the effect that they have on the firm and on the internal barriers (Cagno et al., 2013). To deal with this, we tried to identify the perception of internal stakeholders about barriers arising externally from the firm (as reported Table 6).

Two example could help understand how we came up with the model for the empirical investigation.

- Lack of incentive: the presence of incentives would reduce the cost to the firm of implementing a measure and thus reduce the payback time; correspondingly, without incentives investing in sustainability would be more expensive and/or less profitable, with a likely influence on the 
organizational attitude;

- Uncertainty about future trends: with uncertainty on e.g. energy prices trend, the cost of natural resources or level of fines has a negative impact on organizations' attitude, increasing the risk to implement measures, due to the increased difficulty of identifying hidden costs and evaluating payback time.

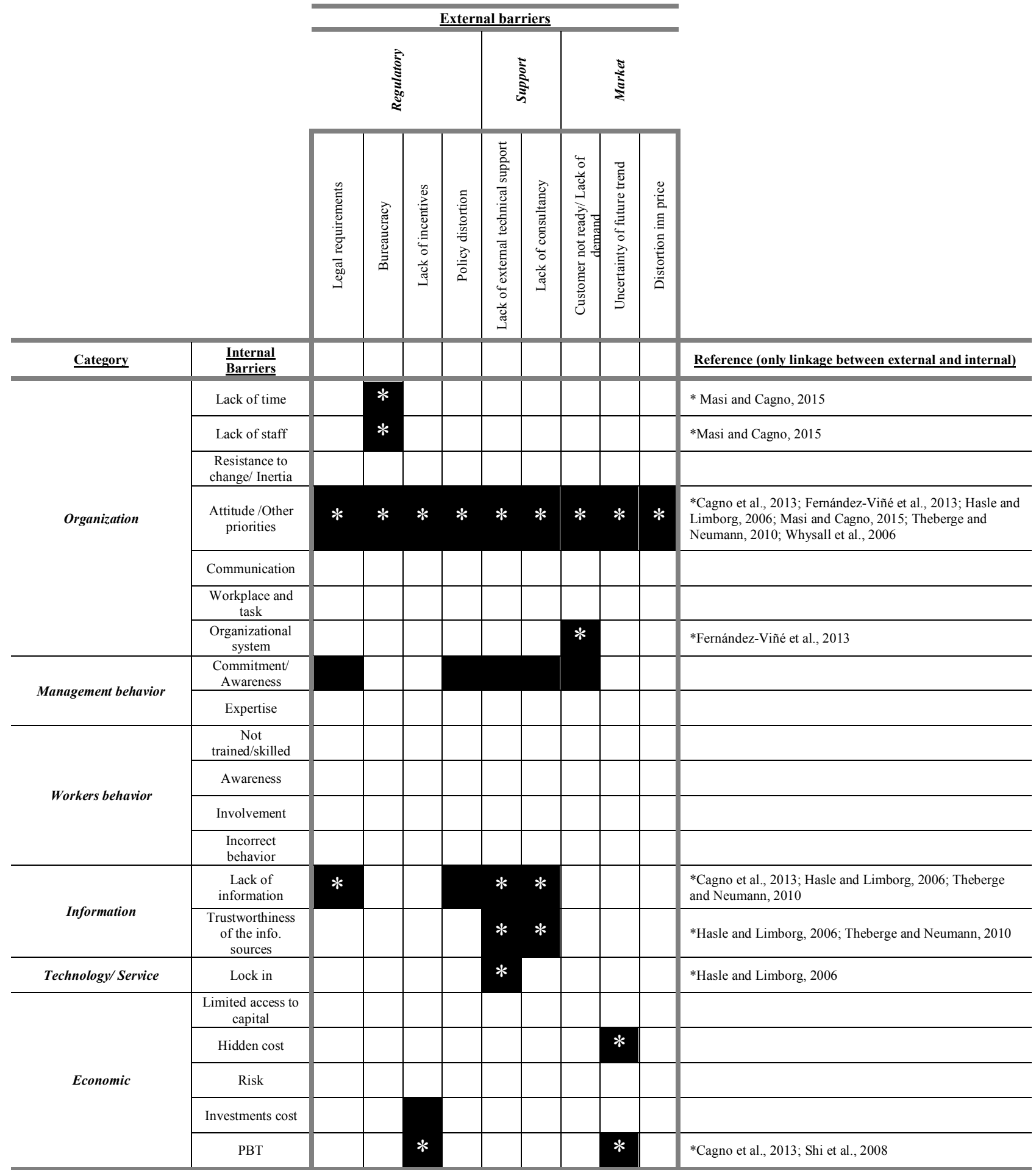

Table 6: Model for the empirical investigation. For each external barrier, it has been tried to understand how internal stakeholders perceive external barriers as internal ones. This linkage is identified by a black box; the white "*” indicates the existence of related literature references (only the boxes with the star have reference). 


\section{Validation of the model}

We decided to perform the investigation using semi-structured case studies with interviews, questionnaires and secondary material. This study fulfils the criteria by Yin (2009), as well as Meredith (1998), Voss et al. (2002) and Zorzini et al. (2008) for case study research: i.e. a situation in which "why", "how" and "what" questions are asked, the investigator has little or no control over events and contemporary events are investigated. Using a semi-structured format allows researchers to structure interviews and ensure that they follow a logical order. We based the interviews around a series of open-ended questions, which were supplemented by questions emerging from the dialogue between interviewer and interviewee, and we also collected free comments, in line with the procedure described by Dicicco-Bloom and Crabtree (2006). We also used multiple sources of evidence (Voss et al., 2002; Yin, 2009) to ensure that findings were corroborated and to increase the validity of the analysis. In particular, our findings were corroborated by collecting and analyzing secondary data, i.e. company websites, reports and direct observations. Interviewees were asked to arrange a tour of their organization's plant for the interviewer to facilitate the collection of secondary data.

According to Yin (2009), four requirements must be met to guarantee the methodological rigor. First, external validity, i.e. the extent to which results can be generalized; this was assessed by defining the domain to which study findings can be generalized. Second, internal validity, i.e. the extent to which casual relationships can be established; this was assessed through pattern matching during data collection. Third, construct validity, i.e. the establishment of operational measures; this was achieved by using multiple sources of evidence (Voss et al., 2002), i.e. semi-structured interviews, questionnaires, direct observations, company website and reports. Fourth, reliability, was addressed with the use of a protocol.

\subsection{Data collection}

The data collection has been organized in three parts. In the first part, we have identified our research sample. More specifically, through the use of a database (AIDA) containing relevant industrial information, we preliminarily identified possible firms for our investigation, selecting them on the basis of their sector, number of employees, turnover and geographical location. We contacted firms by e-mail or phone call. For all those firms that accepted to participate to the research, we looked for secondary company data (company websites, reports, newspapers) regarding companies organization, production processes, as well as material describing (where available) projects, initiatives and similar, towards increased IS.

The second part corresponded to the investigation within the sampled firms where, beyond a tour of the plant, we had a semi-structured face to face interview, supported by a questionnaire as a guide, so to standardize the sequence in which the questions were asked and minimize the impact of contextual effects (Patton, 1990). Finally, we made some concluding questions on the evaluation of the model after having used it. Each interview was audio-recorded and transcribed for analysis. In detail, to start, interviewees were asked to introduce the firm to the interviewer, in terms of sector, production process, number of employees, turnover and attitude toward sustainability. In this way we double-checked public data found in the web, but also explored possible misalignments, in particular regarding interviewees' attitude toward sustainability. Then, through the plant tour we could directly observe and evaluate how the plant worked, and identify possible issues related to IS areas. After the tour, the interview took place. We presented the model of barriers to interviewees, describing every single barrier. Then, we provided interviewees with the list of ISMs, asking them to identify, among the measures, those considered for adoption within their firm. The procedure for the development of the list of measures is provided in 5.2. We enquired interviewees to identify, using the model proposed, the main barriers to the adoption of each selected ISMs. Further, interviewees could discuss possible additional measures missed from the list. The identification of a barrier was followed by a depth analysis. Indeed, for each measure we asked interviewees to recount us the whole steps followed, contextualizing the situation in which the adoption of measure was taken in consideration. 
Then, for each barrier identified, interviewees were asked to explain in detail the impact of that barrier in the specific situation. Main insights and issues emerged from the evaluation of barriers were further investigated. Following, after the evaluation of the barriers, interviewees were asked to rate the relevance of barriers using a four-point Likert scale, where 1 is "not relevant", 2 is "low-medium relevance", 3 is "medium-high relevance" and 4 is "high-very high relevance". Using a Likert scale to collect data on the relevance of barriers enabled us to synthesize the data from all interviewees and provide a quantitative measure, thus supplementing the comments and evaluations. Moreover, a pairwise Likert scale forces the respondent to take a position as there is no neutral position (Cagno and Trianni, 2014). At the end, we asked interviewees to evaluate the novel model of barriers. The evaluation was performed at the end of the interview according to the three performances previously identified, since we considered necessary to make interviewees use the model before asking them to evaluate it.

The third part of the data collection corresponded to the transcription and coding of the interviews and to the identification of possible misalignments emerged. In three our of eight companies investigated, we called back the interviewees, asking for a second face-to-face or phone meeting, for further clarification.

\subsection{Selection of industrial sustainability measures}

The provided list was intended to include the most frequently implemented and most important measures in each area of IS as well as to provide a short list of measures with different impacts on the different areas of IS. The list represents a common basis for evaluating barriers in the different firms. Taking inspiration from Klewitz and Hansen (2014), but limiting their proposed compensation trade-off effect, we defined an ISM as a technical or organizational measure tailored to a firm's characteristics that is intended to improve a firm's overall sustainability performances or practices related to a specific sustainability pillar, whilst having no impact or a positive impact on the others. To produce the list of ISMs, we analyzed 43 contributions (scientific articles; reports; books; company reports; organizational reports and publications; government publications). This resulted in the identification of 52 measures based on data availability and applicability in an industrial context. We classified measures according to their impact on the different IS areas (OHS; EE; EnEff; OHS + EE; OHS + EnEff; EE +EnEff; OEE (i.e. the measure has impact on OHS + EE+ EnEff)). Complete details regarding the classification of the selected measures, descriptions and references, are reported in Annex (Table A1).

\section{Results}

The results of our validation study are divided in two parts. In Section 6.1, we report three out of the eight cases in detail; in Section 6.2 we summarized the results of the full set of sampled firms.

\subsection{Results by single companies.}

\subsubsection{Company 1}

Company 1 is a large firm manufacturing steam engines and power generation boilers focused on the production of turbines (steam and hydraulic), aggregate plant supply (steam and hydraulic), service activities and third party operations. The critical financial position of the company negatively affects the implementation of IS measures: priority is exclusively given to measures able to guarantee the minimum safety requirements, thus overlooking any other thorough change of existing production assets, even with potential relevant benefits in economic and environmental performance. As shown by interviewees, e.g. a re-roofing the whole plant for improved energy efficiency is extremely needed. Nevertheless, this measure is not considered for adoption, because of minimum lighting requirements already satisfied by the existing roof. The firm holds ISO 9001 and ISO 3834-2 certification and it is on its way to re-certificating ISO 14001 and certifying its safety management system.

We have interviewed two members of the health safety and environment (HSE) leadership team and 
a member of the maintenance leadership team, as a representative of the plant management. All the interviewees have judged the model very positively with respect to all three criteria.

One of the two HSE interviewees stated: "This model contains all the things that we need [...] it takes into consideration all the factors that need to be evaluated in a business risk situation, it also covers the legislation: organizational, technical and procedural measures", then adding: "We are aware of our problems and limitations, but having such a model would be very helpful to us in improving our management system."

The second HSE interviewee stated that the model "considers all the aspects in which we are interested." Both the second HSE interviewee and the maintenance interviewee affirmed that having such a ready-made checklist would have been very useful for their firm.

All the interviewees recognized that the main barriers for their firm are related to management and lack of capital. Economic barriers and barriers relating to managerial commitment/awareness mainly affect the implementation of EE and EnEff measures, whilst organization barriers mainly affect OHS measures. Further, lock-in is recognized as critical in almost all the areas of IS. The results are reported in Table 7.

$$
<<\text { Insert Table } 7 \text { around here }>>
$$

\subsubsection{Company 2}

Company 2 is a large firm manufacturing basic pharmaceutical products and pharmaceutical preparations, with focus on active pharmaceutical ingredients, custom synthesis and fine chemicals. It has several plants in Italy and each plant is autonomous, despite general guidelines on sustainability offered by the firm, and implements several quality management systems and environmental sustainability programs, with a focus on environmental safety, health and green chemical processes. In this study we considered one of firm's plant, which can be considered as a medium enterprise.

The interviewee, chief of engineering, with responsibility over HSE issues at plant level, deemed to be able to understand and use the model properly. He has judged it very positively, adding that it is complete, well-structured and offers a comprehensive picture of the issue. In particular, he describes the model as "well structured", also noting that "it could be very useful during the implementation of measures, because it gives one have a comprehensive picture of potentially related problems. " $\mathrm{He}$ also considers the model "very useful for evaluating an investment or a suggested measure, as it would give you advance warning of the problems you would be likely to face."

The interviewee identified investment cost and payback time as the main barriers to OHS measures, investment cost as the main barrier to EE and EnEff measures, and lack of time and lack of staff as the main barriers for the firm in general. When asked to evaluate barriers to implementation of specific measures, economic and organization barriers were mentioned in relation to OHS measures, whilst economic barriers were cited in relation to EnEff measures. The main barriers related to implementation of specific EE measures were economic and organization. The results are reported in Table 8.

$$
<<\text { Insert Table } 8 \text { around here }>>
$$

\subsubsection{Company 3}

Company 3 is a small energy-intensive manufacturer of agricultural machineries, founded in 1983 and with steady and rapid growth. The firm is a member of a Quality Assurance Service, with also ISO 9001 certification. We interviewed two members of the leadership team, respectively the energy and environment manager and the OHS manager.

Both interviewees judged the ability to represent and ease of use of the model very positively, but, interestingly, they had different opinions on its usefulness in the specific context. The first interviewee considered that only some of the IS barriers' categories (i.e. information, technology and economic barriers) would effectively describe the barrier, asserting that the firm does not face any relevant internal barriers related to organization, management behavior and workers behavior. 
Nevertheless, he pointed out that "my observations are related to our business context, that of a small-medium enterprise that operates globally [...] You will find that other firms give different answers because of their different characteristics". The OHS interviewee, on the other hand, said the model could be useful for understanding the different types of ISMs and that it had helped him to identify a previously unrecognized barrier. According to him, the model "describes the set of problems well", and noted that "yes, I would have not considered the training... we should give serious thought to worker training."

Barriers identified at a general level are lack of awareness, low worker involvement, lock-in and economic barriers. The main barriers to implementation of specific OHS measures are lock-in and wrong behavior of workers, whilst the main barriers to implementation of specific EE and EnEff measures are economic. The results are reported in Table 9.

$$
<<\text { Insert Table } 9 \text { around here }>>
$$

Despite it does not specifically fall under the scope of the present research, it is really important to note that the application of a model in a context where multiple decision-makers on IS are involved, showed the capability of our innovative model to gather different perspectives regarding IS within the same company, thus pinpointing possible mismatches, conflicts etc. regarding decision-making over the adoption of ISMs. 
EnEff - More

OHS - Guards OHS - Safety sheets EnEff - Detection efficient lamps/ EnEff - Solar panels elimination of leaks light sources (not installation (not done)

OHS + EnEff - EnEff + EE - Mor Preventive efficient type of

EnEff + EE -

$$
\text { done) }
$$

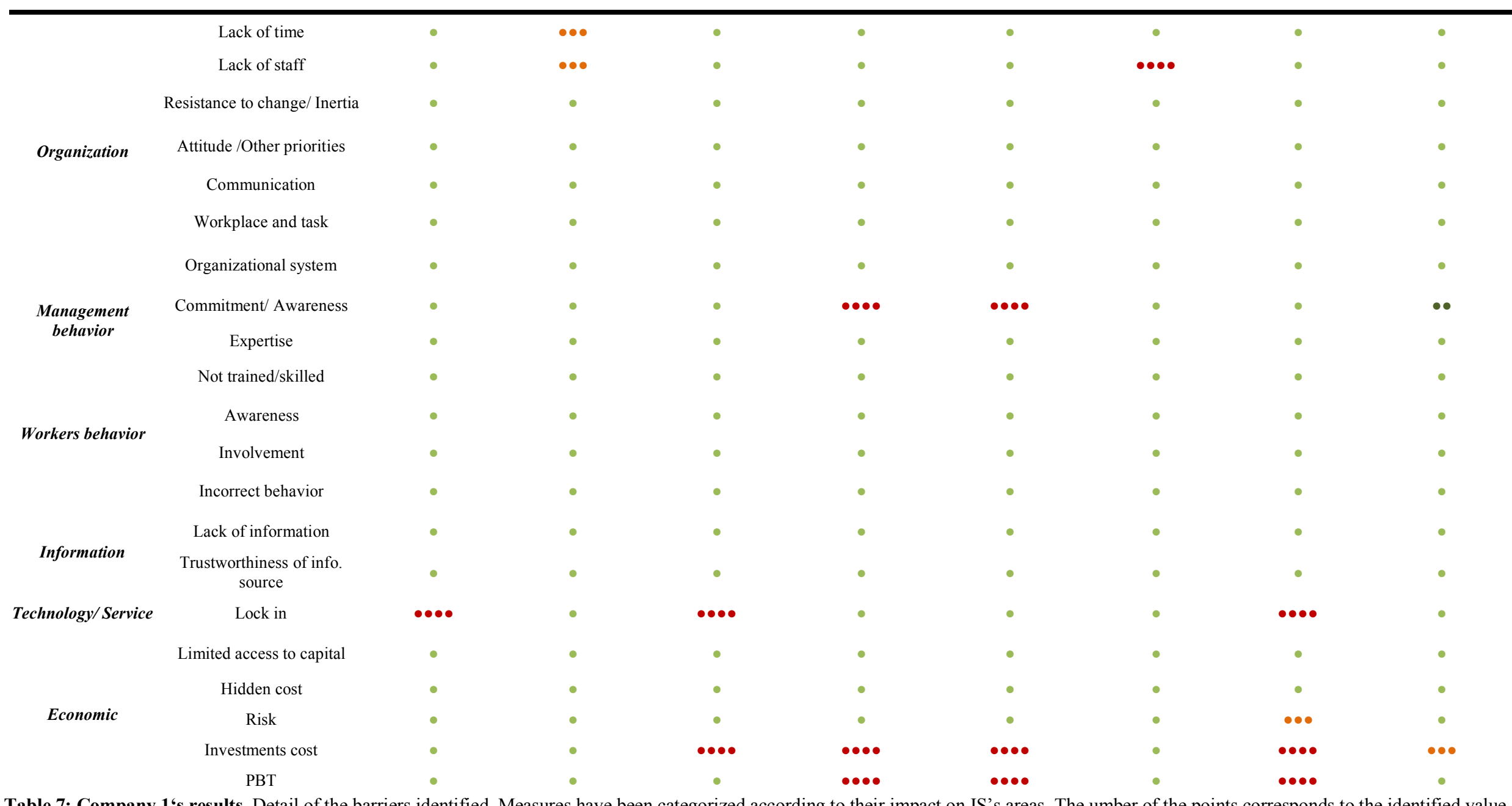

Table 7: Company 1's results. Detail of the barriers identified. Measures have been categorized according to their impact on IS's areas. The umber of the points corresponds to the identified value of the Likert-like scale (one point, light green: value 1, "not relevant"; two point, dark green: value 2, "low-medium relevance"; three points, orange: value 3, "medium-high relevance"; four points, red: value 4, "high-very high relevance"). 


\begin{tabular}{|c|c|c|c|c|c|c|c|c|c|c|c|c|c|c|c|c|}
\hline & & OHS - PPE & $\begin{array}{c}\text { OHS - } \\
\text { Emergency } \\
\text { Buttons }\end{array}$ & $\begin{array}{c}\text { OHS - } \\
\text { Replacement } \\
\text { of machine }\end{array}$ & $\begin{array}{l}\text { OHS - } \\
\text { Training on } \\
\text { safety } \\
\text { procedures }\end{array}$ & $\begin{array}{l}\text { OHS- } \\
\text { Hazards/ } \\
\text { accidents } \\
\text { record }\end{array}$ & $\begin{array}{c}\text { EE - } \\
\text { Environmental } \\
\text { performance }\end{array}$ & $\begin{array}{l}\text { EE - Modify } \\
\text { the process } \\
\text { to reduce the } \\
\text { use of water }\end{array}$ & $\begin{array}{l}\text { EnEff - } \\
\text { More } \\
\text { efficient } \\
\text { lamps/ light } \\
\text { sources }\end{array}$ & $\begin{array}{c}\text { EnEff }+\mathbf{E E} \\
\text { - More } \\
\text { efficient } \\
\text { type of } \\
\text { motors }+ \\
\text { Right size of } \\
\text { motoris } \\
\end{array}$ & $\begin{array}{c}\text { EnEff + EE } \\
\text { - Inverter }\end{array}$ & $\begin{array}{c}\text { EnEff }+\mathbf{E E} \\
\text { - Modify the } \\
\text { process to } \\
\text { reduce } \\
\text { material } \\
\text { use } / \text { cost }\end{array}$ & $\begin{array}{c}\text { OHS + } \\
\text { EnEff - } \\
\text { Preventive } \\
\text { Maintenance }\end{array}$ & $\begin{array}{c}\text { OHS + EE - } \\
\text { Hazardous } \\
\text { substances } \\
\text { register }\end{array}$ & $\begin{array}{c}\text { OHS + EE - } \\
\text { Replace } \\
\text { toxic/ } \\
\text { dangerous } \\
\text { material }\end{array}$ & $\begin{array}{l}\text { OHS - } \\
\text { Pollution/ } \\
\text { contaminant } \\
\text { reduction }\end{array}$ \\
\hline \multirow{7}{*}{ Organization } & Lack of time & $\bullet$ & - & - & $\bullet \bullet$ & $\bullet \bullet$ & $\bullet \bullet$ & $\bullet$ & - & - & - & $\bullet \bullet$ & - & $\bullet \bullet$ & - & $\bullet$ \\
\hline & Lack of staff & $\bullet$ & - & - & $\bullet \bullet$ & $\bullet \bullet$ & $\bullet \bullet$ & - & - & - & $\bullet$ & $\bullet$ & $\bullet \bullet$ & $\bullet \bullet$ & - & - \\
\hline & $\begin{array}{l}\text { Resistance to change/ } \\
\text { Inertia }\end{array}$ & $\bullet$ & $\bullet$ & • & $\bullet$ & $\bullet$ & $\bullet$ & $\bullet$ & - & $\bullet$ & • & - & $\bullet$ & - & $\bullet$ & - \\
\hline & Attitude /Other priorities & $\bullet$ & - & - & - & - & $\bullet$ & $\bullet$ & - & $\bullet$ & - & - & $\bullet$ & - & - & $\bullet$ \\
\hline & Communication & $\bullet$ & - & - & - & - & - & $\bullet$ & - & - & - & $\bullet$ & $\bullet$ & - & - & $\bullet$ \\
\hline & Workplace and task & $\bullet$ & - & - & - & - & - & $\bullet$ & - & - & - & $\bullet$ & $\bullet$ & - & - & - \\
\hline & Organizational system & - & - & - & - & - & - & $\bullet$ & - & - & - & - & - & - & - & - \\
\hline \multirow{2}{*}{$\begin{array}{l}\text { Management } \\
\text { behavior }\end{array}$} & Commitment/ Awareness & - & - & - & $\bullet$ & • & - & - & $\bullet$ & - & - & - & - & - & - & - \\
\hline & Not trained/skilled & - & - & - & $\bullet$ & $\bullet$ & - & $\bullet$ & - & $\bullet$ & - & $\bullet$ & $\bullet$ & $\bullet$ & - & $\bullet$ \\
\hline \multirow{3}{*}{$\begin{array}{l}\text { Workers } \\
\text { behavior }\end{array}$} & Awareness & - & $\bullet$ & - & $\bullet$ & - & - & $\bullet$ & - & • & • & - & • & • & - & • \\
\hline & Involvement & - & - & $\bullet$ & - & $\bullet$ & - & $\bullet$ & $\bullet$ & $\bullet$ & - & $\bullet$ & $\bullet$ & $\bullet$ & - & - \\
\hline & Incorrect behavior & $\bullet$ & - & - & $\bullet \bullet$ & - & - & $\bullet$ & $\bullet$ & - & - & - & $\bullet$ & • & - & $\bullet$ \\
\hline \multirow{2}{*}{ Information } & Lack of information & - & - & $\bullet$ & - & - & - & - & - & $\bullet$ & - & $\bullet$ & $\bullet$ & - & - & - \\
\hline & $\begin{array}{l}\text { Trustworthiness of info. } \\
\text { source }\end{array}$ & - & $\bullet$ & $\bullet$ & $\bullet$ & - & - & $\bullet$ & $\bullet$ & - & $\bullet$ & - & - & - & - & $\bullet$ \\
\hline \multirow[t]{2}{*}{$\begin{array}{l}\text { Technology/ } \\
\text { Service }\end{array}$} & Lock in & $\bullet$ & $\bullet$ & $\bullet$ & $\bullet$ & $\bullet$ & $\bullet$ & $\bullet$ & $\bullet$ & $\bullet$ & $\bullet$ & - & $\bullet$ & $\bullet$ & $\bullet$ & $\bullet$ \\
\hline & Limited access to capital & - & $\bullet \bullet$ & $\bullet \bullet$ & $\bullet$ & $\bullet$ & - & $\bullet \bullet$ & $\bullet \bullet$ & $\bullet \bullet$ & - & - & $\bullet \bullet$ & - & - & $\bullet \bullet \bullet$ \\
\hline \multirow{3}{*}{ Economic } & Hidden cost & $\bullet$ & - & - & - & - & - & $\bullet$ & - & - & - & - & $\bullet$ & - & - & - \\
\hline & Risk & $\bullet$ & - & $\bullet \bullet$ & - & $\bullet$ & - & $\bullet$ & $\bullet$ & $\bullet$ & - & - & - & $\bullet$ & $\bullet$ & - \\
\hline & Investments cost & $\bullet$ & $\bullet \bullet$ & $\bullet \bullet$ & - & - & - & $\bullet \bullet$ & $\bullet \bullet$ & $\bullet \bullet$ & - & - & $\bullet \bullet$ & - & $\bullet$ & $\bullet \bullet \bullet$ \\
\hline
\end{tabular}

Table 8: Company 2's results. Detail of the barriers identified. Measures have been categorized according to their impact on IS's areas. The umber of the points corresponds to the identified value of the Likert-like scale (one point, light green: value 1, "not relevant"; two point, dark green: value 2, "low-medium relevance"; three points, orange: value 3, "medium-high relevance"; four points, red: value 4, "high-very high relevance"). 


\begin{tabular}{|c|c|c|c|c|c|c|c|c|c|c|c|c|}
\hline & & $\begin{array}{c}\text { OHS - Lifting } \\
\text { System }\end{array}$ & OHS - Guards & $\begin{array}{l}\text { OHS - Safety } \\
\text { sheets }\end{array}$ & OHS - PPE & $\begin{array}{l}\text { EE - Modify } \\
\text { the process for } \\
\text { use different } \\
\text { raw material }\end{array}$ & $\begin{array}{c}\text { EnEff - Solar } \\
\text { panel } \\
\text { installation }\end{array}$ & $\begin{array}{c}\text { EnEff - More } \\
\text { efficient } \\
\text { lamps/ light } \\
\text { source }\end{array}$ & $\begin{array}{l}\text { EnEff - } \\
\text { Detection/ } \\
\text { elimination of } \\
\text { leaksZ }\end{array}$ & $\begin{array}{c}\text { OEE - } \\
\text { Performance } \\
\text { (environment) }\end{array}$ & $\begin{array}{c}\text { OHS + EnEff } \\
\text { - Preventive } \\
\text { Maintenance }\end{array}$ & $\begin{array}{c}\text { OHS + EE - } \\
\text { Replace toxic } \\
\text { dangerous } \\
\text { material }\end{array}$ \\
\hline \multirow{7}{*}{ Organization } & Lack of time & - & - & - & - & - & - & - & - & 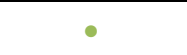 & $\bullet$ & 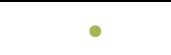 \\
\hline & Lack of staff & - & - & - & - & - & - & - & - & - & $\bullet \bullet$ & - \\
\hline & Resistance to change/ Inertia & - & - & - & - & - & - & - & - & - & - & $\bullet$ \\
\hline & Attitude /Other priorities & - & - & $\bullet \bullet \bullet$ & - & - & - & - & - & - & $\bullet$ & - \\
\hline & Communication & - & - & - & - & - & - & - & - & - & - & - \\
\hline & Workplace and task & - & - & - & - & - & - & - & - & - & - & - \\
\hline & Organizational system & - & $\bullet$ & - & - & - & • & • & - & $\bullet$ & - & - \\
\hline \multirow{3}{*}{$\begin{array}{l}\text { Management } \\
\text { behavior }\end{array}$} & Commitment/ Awareness & - & - & - & - & $\bullet$ & - & - & - & - & $\bullet$ & $\bullet$ \\
\hline & Expertise & - & - & - & - & - & - & - & - & - & - & - \\
\hline & Not trained/skilled & - & - & - & - & - & - & - & - & - & $\bullet \bullet$ & $\bullet$ \\
\hline \multirow{3}{*}{ Workers behavior } & Awareness & - & $\bullet$ & - & - & - & $\bullet$ & - & - & - & - & - \\
\hline & Involvement & - & - & - & - & - & - & - & - & $\bullet$ & - & $\bullet$ \\
\hline & Incorrect behavior & $\bullet$ & $\bullet \bullet$ & - & $\bullet$ & - & - & - & - & - & $\bullet$ & - \\
\hline \multirow{2}{*}{ Information } & Lack of information & - & $\bullet$ & - & - & • & - & - & - & $\bullet$ & - & $\bullet$ \\
\hline & Trustworthiness of info. source & - & - & - & - & - & - & - & - & - & - & - \\
\hline $\begin{array}{l}\text { Technology/ } \\
\text { Service }\end{array}$ & Lock in & $\bullet$ & $\bullet \bullet$ & - & - & - & - & - & - & - & - & $\bullet \bullet$ \\
\hline \multirow{5}{*}{ Economic } & Limited access to capital & - & - & - & - & - & - & - & - & - & - & - \\
\hline & Hidden cost & $\bullet \bullet$ & - & - & - & $\bullet \bullet$ & - & - & $\bullet \bullet$ & - & $\bullet \bullet$ & - \\
\hline & Risk & - & $\bullet \bullet$ & - & - & $\bullet$ & - & - & - & - & - & - \\
\hline & Investments cost & - & - & $\bullet \bullet$ & - & $\bullet \bullet$ & $\bullet \bullet$ & $\bullet \bullet$ & - & $\bullet \bullet$ & - & - \\
\hline & PBT & - & - & - & - & - & - & - & - & - & - & - \\
\hline
\end{tabular}

Table 9: Company 3's results. Detail of the barriers identified. Measures have been categorized according to their impact on IS's areas. The umber of the points corresponds to the identified value of the Likert-like scale (one point, light green: value 1, "not relevant"; two point, dark green: value 2, "low-medium relevance"; three points, orange: value 3, "medium-high relevance"; four points, red: value 4, "high-very high relevance"). 


\subsection{Whole sample}

We here base our evaluation of the model on the judgments of all the thirteen interviewees, rather than on firms' overall judgments, as in some cases interviewees from the same firm had slightly differing opinions. This is a very interesting result, as it illustrates the existence of different perspectives on barriers to implementation of ISMs, even within a firm, and is in line with a strand of literature that emphasizes the importance of considering the varying perspectives of all decisionmakers when implementing a measure (Cagno and Trianni, 2014; Reddy, 2013; Thollander and Palm, 2012).

The results of this preliminary validation study were positive with respect to all three performances (as shown in Figure 2, while the main findings from each case study can be found in Table 10). Regarding ability to represent, the model was judged complete and all the thirteen interviewees considered the barriers specified in the model to be sufficiently distinct and detailed. For what concerns usefulness, the model makes hidden barriers emerge, and widely helps interviewees better structure what they may have already in mind; moreover, almost all the interviewees judged the model as very useful for the designing and implementation of measures, but also to provide a valid and quick help for the identification of barriers. Indeed, in some firms investigated, interviewees affirmed they tried to developed approaches in order to identified problems related to the adoption of ISMs, but these approaches were not comprehensive or structured as the one proposed. Concerning ease of use, the model resulted very easy to use for the vast majority of interviewees; but, it is worth noting that also who deemed the model as a bit complex, offered here a quite positive judgment, highlighting that it was worth to use it because of the high quality of the information provided.

Figure 2: Results of the validation of the new model

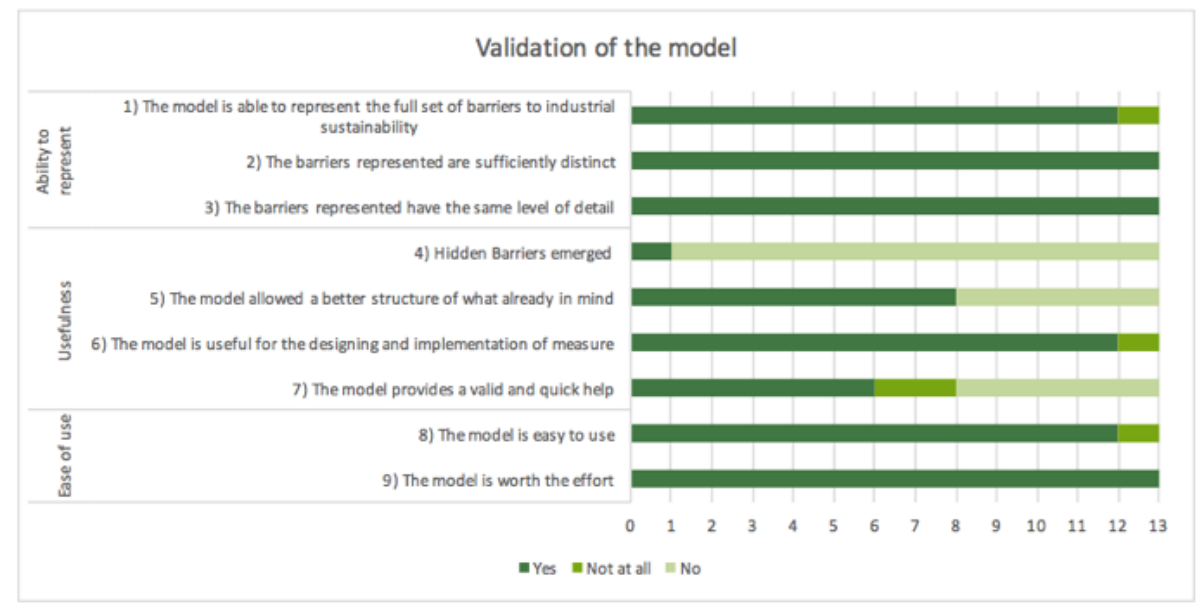

\begin{tabular}{|c|c|c|}
\hline & Person interviewed & Main Comments Emerged \\
\hline \multirow[t]{3}{*}{ Company 1} & $\begin{array}{l}\text { Health Safety and } \\
\text { Environment Manager } 1\end{array}$ & $\begin{array}{l}\text { "The model contains all the things that we need [...] it takes in considerations all the } \\
\text { relevant aspects that need to be evaluated in a risk business situation, also according to } \\
\text { legislation: organizational, technical and procedural measures" "We are aware of our } \\
\text { problems and limitations, but having such a model would be very helpful in order to } \\
\text { improve our management system". }\end{array}$ \\
\hline & $\begin{array}{l}\text { Health Safety and } \\
\text { Environment Manager } 2\end{array}$ & "It considers all the aspects in which we are interested in" \\
\hline & Maintenance Manager & Positive judgment of the model \\
\hline Company 2 & $\begin{array}{l}\text { Health Safety and } \\
\text { Environment Manager }\end{array}$ & $\begin{array}{l}\text { "Well structured" } \\
\text { "Very useful during the implementation of measures, because it allows to have a } \\
\text { complete view on those that could be the related problems" }\end{array}$ \\
\hline Company 3 & OHS Manager & $\begin{array}{l}\text { Positive judgment of all the model. } \\
\text { Identification of a new barrier: "I would have not considered the training... we should } \\
\text { give serious thought to workers training" } \\
\text { Considered the whole model as an outline for the design and implementation of } \\
\text { measures }\end{array}$ \\
\hline
\end{tabular}




\begin{tabular}{|c|c|c|}
\hline & $\begin{array}{l}\text { Energy and Environmental } \\
\text { Manager }\end{array}$ & $\begin{array}{l}\text { Considered as significant only the last part of the model. I would use only the last part } \\
\text { of the model, that I think are the keys points. }\end{array}$ \\
\hline Company 4 & OHS Manager & "It would have been difficult for me to create such a model" \\
\hline \multirow[t]{2}{*}{ Company 5} & OHS Manager & "Personally, thanks to my experience I had already identified the barriers" \\
\hline & Technical Director & $\begin{array}{l}\text { "Absolutely useful for the implementation of Industrial Sustainability measures" } \\
\text { "I would have not been able to identify all the barriers on my own" }\end{array}$ \\
\hline Company 6 & $\begin{array}{l}\text { Health Safety and } \\
\text { Environment Manager }\end{array}$ & $\begin{array}{l}\text { The model resulted interesting also in a company that already have an internal system } \\
\text { for the evaluation of measures. }\end{array}$ \\
\hline Company 7 & $\begin{array}{l}\text { Health Safety and } \\
\text { Environment Manager }\end{array}$ & $\begin{array}{l}\text { The model resulted interesting also in a company that already have an internal system } \\
\text { for the evaluation of measures. } \\
\text { It helped the manager to focus better on Information related barriers }\end{array}$ \\
\hline Company 8 & CEO & $\begin{array}{l}\text { "It could be useful as a structure on which moving" } \\
\text { Company } 8 \text { was the only one to find difficulties in using the model, stating however } \\
\text { difficulties were totally overcame by the fact of having an already done model like the } \\
\text { one proposed. }\end{array}$ \\
\hline
\end{tabular}

Table 10: Main comments emerged from investigation

\section{Discussion and conclusion}

Sustainability is becoming more and more relevant. Focusing on IS areas, i.e. OHS, EE, EnEff, firms can improve there IS performance adopting measures whose implementation is hindered by barriers. Extant literature does not offer so far a comprehensive model of all the barriers to IS that covered all areas.

In this study we have presented a novel model, aimed at giving a contributing in addressing the aforementioned gaps. The model is based on barriers identified in the literature review and specifies nine categories of barriers, both external (regulatory, support and market barriers) and internal (organization, management behavior, worker behavior, information, technology/service and economic barriers).

We have successfully conducted the preliminary validation of the new model thanks to semistructured case studies into northern Italy manufacturing firms. People responsible for different areas of IS (i.e., energy, environment and safety) evaluated the model as able to represent the full set of barriers to IS with sufficient distinction among them and with same level of detail. Moreover, when applying our model, they appreciated the capability to point out hidden barriers, but also to offered a structured view on already identified barriers to the adoption of ISMs, with valuable information offered in a simple way.

Despite the exploratory nature of this preliminary investigation among companies (that for sure needs to be complemented with further empirical research), we have shown the existence of similarities and differences in the barriers to implementation of measures in the different IS areas. Several of the main barriers to implementation of ISMs that were identified by firms are relevant to IS generally. In particular, organization and the economic barriers affect specific areas of IS as well as IS more generally. In the following specific examples are reported:

- Lack of time and lack of staff where considered the most important organization barriers confirming e.g. (Maximiano, 2005) for IS, (EASHW, 2010) for OHS, (Chan, 2008) for EE, (Sorrell et al., 2000) for EnEff;

- Investment cost and payback time were considered the most important economic barriers, confirming e.g. (Collins et al., 2010) for IS, (Quinlan and Mayhew, 2000) for OHS, (Zilahy, 2004) for EE, (Anderson and Newell, 2004) for EnEff;

- Lock-in barrier had independent effects on all three areas;

- Incorrect behaviour of workers was considered to have a large impact on implementation of OHS measures, confirming (Whysall et al., 2006)

- Economic barriers' relevance is in line with the extant literature on trade-offs among the different factors related to IS, in particular trade-offs between social/environmental factors and economic performance (Beckmann et al., 2014; Haffar and Searcy, 2017).

Another important finding relates to barriers to implementation of specific measures. First, the main 
barriers to implementation of measures related to specific IS areas by our interviewees were not mentioned in the literature on that IS area. This was the case for lock-in as a barrier to OHS measures and incorrect behavior of workers as a barrier to EnEff. Secondly, main barrier to a measure related to a specific IS area was not identified as a main barrier by the empirical literature of that area, i.e., payback time in the case of OHS, lock-in in the case of EE and communication in the cases of OHS and EnEff. This demonstrates that barriers to the implementation of ISMs are worth being analyzed using an integrative model that encompasses all IS areas; moreover, it shows that there may be specific barriers to implementation of specific measures that are different from the barriers identified at a general level. This last finding corroborates the results of a study of barriers to specific EnEff measures (Cagno and Trianni, 2014). We also demonstrated the existence of different perspectives among people in different positions of responsibility. In particular, different perspectives were observed both regarding barriers to specific ISMs and the validation of the model. This extends (Cagno and Trianni, 2014) findings and confirmed also (Reddy, 2013; Thollander and Palm, 2012). Our model of the barriers to implementation of ISMs is certain to be of great interest to industrial decision-makers, as it will help them organize their resources and develop an implementation strategy. Indeed, from the validation of the model, it emerged that interviewees express an overall positive judgement on the utility of the model as in valid help for the identifications of all the barriers related to an ISM adoption. Company managers, after a proper identification and evaluation of the different perspectives on sustainability, could develop most effective ways to tackle barriers and improve sustainability within their firm. The model should also be of interest to policy-makers as it may help them to develop a regulatory framework, design incentives to encourage industry to adopt measures and identify the most effective methods of enhancing IS within firms.

One limitation of the study is that, considering the sample investigated, it was not possible to interview the desired professional figures in all the firms, i.e. one for each area of IS, and so different perspectives have not been evaluated in every firm. Moreover, it should be pinpointed that the study has been developed focusing on specific areas of IS (OHS, EE, EcoEff), thus limiting the scope and not addressing implications related to the remaining areas of sustainability in general terms.

From a theoretical perspective, our study, currently focused on barriers to the adoption of ISMs, opens several streams of future research. Here, we see large room for addressing drivers to the adoption of ISMs, so to overcome existing barriers. Furthermore, research could focus on a joint modelling and analysis of the barriers and drivers related to the implementation of ISM, as well as considering how the perspectives of people with different areas of responsibility from the same firm may differ on the adoption of the same ISM. Indeed, because of their different backgrounds, aims and commitments, different people may have differing perceptions of the barriers to the implementation of specific measures. Additionally, to give a broad vision on the issues related to the implementation of ISMs, it would be of great interest to evaluate the mechanism between barriers and drivers, so to more precisely pinpoint policy-making actions to foster ISMs.

From an empirical perspective, valuable findings could come from model's application to a set of various clusters of enterprises, e.g. differing with respect to sector, size, labor and capital intensity, energy intensity, etc. This would lead to a specific identification and evaluation of similarities and differences in the barriers according to different types of enterprise experience in relation to the adoption of ISMs. Interestingly, differences in perspectives over IS could also be analyzed by proper clustering of companies according to related to firms' characteristics (e.g. size, sector, geographical region, general behavior towards sustainability). Such an analysis would provide a basis for describing the set of relationships underlying the implementation of an ISM, i.e. evaluating whether implementation of a specific ISM related to an IS area can be facilitated or hindered by factors related to another area of IS, as well as from e.g., struggling forces between different industrial decisionmakers within the same firm. Finally, it would be great not only to model, but also to empirically evaluate barriers and drivers to the adoption of ISMs according to the adoption key performance indicators for sustainability, so to see how companies with different sustainability performance behave with respect to barriers and drivers to the adoption of IS measures. 


\section{Annex}

Table A1: Selected measures with description, references and impact.

\begin{tabular}{|c|c|c|c|c|}
\hline Type & Name & Description & References & Impact \\
\hline \multirow[t]{4}{*}{ Motors } & Energy-efficient Belts & Substitution of belts with more energy efficiency ones & $\begin{array}{l}\text { Carbon Trust, 2011c; De Almeida and Greenberg, 1995; } \\
\text { IAC, 2007; Trianni et al., 2014; U.S Department of Energy, } \\
2005\end{array}$ & ENEFF+EE \\
\hline & Right size & Substitution of an oversized motor (typically used under $50 \%$ of load) with a more appropriate sized one. & $\begin{array}{l}\text { Carbon Trust, 2011a; IAC, 2007; Saidur et al., 2012; Trianni } \\
\text { et al., 2014 }\end{array}$ & ENEFF+EE \\
\hline & More efficient type of motors & $\begin{array}{l}\text { Substitution of the motor whit a more efficient one. A HEM (High Efficiency Motor) is defined whose efficiency class is at } \\
\text { least one or more grades higher than the market average }\end{array}$ & $\begin{array}{l}\text { Cagno and Trianni, 2012; Carbon Trust, 2011a; Carbon } \\
\text { Trust, 2011c; De Almeida et al., 2003; IAC, 2007; Trianni et } \\
\text { al., 2014 }\end{array}$ & ENEFF+ EE \\
\hline & Inverter (VSD/AFD) & Device that modulates the power frequency or fan electric motor and then his speed as a function of load & $\begin{array}{l}\text { Abdelaziz et al, 2011; De Almeida et al, 2003; De Almeida } \\
\text { et al., 2005; Ferreira et al., 2011; IAC, 2007; Trianni et al., } \\
2014\end{array}$ & ENEFF+EE \\
\hline \multirow[t]{5}{*}{ Lighting } & Use daylight & Use daylight as much as possible. & IAC, 2007; Li et al., 2010; Trianni et al., 2014 & $\begin{array}{l}\text { ENEFF+ } \\
\text { OHS }\end{array}$ \\
\hline & Reduce illumination (to minimum safe level) & Reduce the over-illumination of an area to minimum safe level so that activities can be carried out safely. & IAC, 2007; Trianni et al., 2014 & ENEFF \\
\hline & More efficient lamps/light source & Use more efficient type of lamp or light source & $\begin{array}{l}\text { Cagno and Trianni, 2012; Gaglia et al., 2007; IAC, 2007; } \\
\text { Mahlia et al., 2011; Trianni et al., } 2014\end{array}$ & ENEFF \\
\hline & 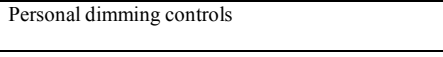 & $\begin{array}{l}\text { Provide workstations with personal dimming controls so that employees are able to adjust the level of illumination according } \\
\text { to their need. }\end{array}$ & $\begin{array}{l}\text { Boyce et al., 2006; IAC, 2007; Jones and Richman, 2005; } \\
\text { Trianni et al., 2014 }\end{array}$ & $\begin{array}{l}\text { ENEFF+ } \\
\text { OHS }\end{array}$ \\
\hline & $\begin{array}{l}\text { Presence sensors } \\
\text { Pight size fcompressor }\end{array}$ & Install presence sensor in order to make the light turn on only when necessary (person in the room) & Cagno and Trianni, 2012; IAC, 2007; Trianni et al., 2014 & ENEFF \\
\hline \multirow[t]{3}{*}{ Compressed Air } & $\begin{array}{l}\text { Right size of compressor } \\
\text { Pressure of compressed air to minimum required }\end{array}$ & $\begin{array}{l}\text { Reduce the size of the air compressors (part load is very inefficient) } \\
\text { Because of pressures higher than those recommended the degree of usury increases. }\end{array}$ & $\begin{array}{l}\text { CAC, 2003; IAC, 2007; Trianni et al., } 2014 \\
\text { CAC, 1998b; CAC, 2003; Cagno and Trianni, 2012; IAC, } \\
\text { 2007; Trianni et al., 2014 }\end{array}$ & $\begin{array}{l}\text { ENEFF } \\
\text { ENEFF }\end{array}$ \\
\hline & Detection/elimination of leaks & Identification of leaks in the air compressed system and subsequent elimination. & $\begin{array}{l}\text { Abdelaziz et al, 2011; CAC, 1998a, 2003; Cagno and } \\
\text { Trianni, 2012; IAC, 2007; Trianni et al., 2014 }\end{array}$ & ENEFF \\
\hline & Intakes in coolest location & Site the air compressed system in a coolest location. & Cagno and Trianni, 2012; IAC, 2007; Trianni et al., 2014 & ENEFF \\
\hline \multirow[t]{5}{*}{ HVAC } & More efficient HVAC unit & Improve the energy efficiency of the system; the improvement is possible also changing one of the components & $\begin{array}{l}\text { Carbon Trust, 2011b; Gaglia et al., 2007; IAC, 2007; Trianni } \\
\text { et al., 2014 }\end{array}$ & ENEFF \\
\hline & Right size of HVAC unit & Substitution of an oversized HVAC system & $\begin{array}{l}\text { IAC, 2007; Trianni et al., 2014; U.S Department of Energy, } \\
2002\end{array}$ & ENEFF \\
\hline & Lower ceiling o reduce conditioning space & Lower ceilings or reduce space that need air conditioning in order to use less energy & IAC, 2007; Trianni et al., 2014 & ENEFF \\
\hline & $\begin{array}{l}\text { Air conditioning only when/where necessary } \\
\text { Reduce air ventilation to minimum }\end{array}$ & $\begin{array}{l}\text { Use air condition in places or times in which it is necessary } \\
\text { Make air ventilation less necessary finding alternative method }\end{array}$ & $\begin{array}{l}\text { IAC, 2007; Trianni et al., } 2014 \\
\text { Carbon Trust, 2011b; IAC, 2007; Trianni et al., 2014 }\end{array}$ & $\begin{array}{l}\text { ENEFF } \\
\text { ENEFF }\end{array}$ \\
\hline & Personalized ventilation & Every employee, through personal devices, can control and optimize temperature, speed and direction of his "personal air" & IAC, 2007; Melikov, 2004; Trianni et al., 2014 & $\begin{array}{l}\text { ENEFF+ } \\
\text { OHS }\end{array}$ \\
\hline \multirow[t]{6}{*}{ Training } & Energy awareness & Make the employee and the management aware or more aware about energy issue & & ENEFF+EE \\
\hline & Energy saving related to equipment & $\begin{array}{l}\text { Adequate training to make those who use the machinery aware of the energy expenditures of the equipment and the ways to } \\
\text { reduce them. }\end{array}$ & & ENEFF \\
\hline & Training on machinery & $\begin{array}{l}\text { Adequate training should ensure that those who use the machinery are competent to use it safely. This includes ensuring they } \\
\text { have the correct skills, knowledge, and experience and risk awareness. Sometimes formal qualifications are needed, e.g. for } \\
\text { chainsaw operators. }\end{array}$ & $\begin{array}{l}\text { Cagno et al., 2014; Gardner et al., 1999; HSE, 2012b; HSE, } \\
\text { 2013a; HSE, 2013c }\end{array}$ & OEE \\
\hline & Training on safety procedures & Safety procedures training. It can be referred both to basic training and to particular procedures within the firm. & $\begin{array}{l}\text { Cagno et al., 2014: Gardner et al., 1999; Hale et al., 2010; } \\
\text { HSE, 2013a; Novartis, } 2014 \text {, }\end{array}$ & OHS \\
\hline & Training on environmental impacts & $\begin{array}{l}\text { Training about the environmental impact of industrial activities in general and/or about the (potential) environmental impact of } \\
\text { the firm's activities. }\end{array}$ & Barbeau et al., 2004 & ENEFF+EE \\
\hline & $\begin{array}{l}\text { Training on consequences of non-compliance with } \\
\text { environmental procedures }\end{array}$ & Adequate training about the consequences of an improper behavior of an employee & & OEE \\
\hline \multirow[t]{3}{*}{ Staff } & Job rotation & $\begin{array}{l}\text { Job rotation involves an employee changing positions within the same organization and eventually returning to the original } \\
\text { position. It can refer to different types of rotations: task rotation, position rotation }\end{array}$ & NYCOSH, 2014 & OHS \\
\hline & Redefinition of organizational procedures & Redefinition of organizational procedure to better ensure safety & Barbeau et al., 2004; Micheli and Cagno, 2008 & $\mathrm{OHS}$ \\
\hline & Medical check-up for workers & Medical check-up are established according to the level of risk to which each employee is exposed & & OHS \\
\hline \multirow[t]{5}{*}{ 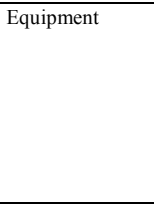 } & Preventive Maintenance & Maintenance measure is performed before failure occurrence & $\begin{array}{l}\text { ACCI, 2004; Barbeau et al, 2004; Furlanetto et al., 2006; } \\
\text { HSE, 2012b; HSE, 2013c }\end{array}$ & OHS+ENEFF \\
\hline & Guards & $\begin{array}{l}\text { Use fixed guards to enclose, whenever practicable, machinery's moving parts. } \\
\text { Use best material for these guards. If fixed guards are not practicable, } \\
\text { Use other methods, eg interlock the guard. }\end{array}$ & HSE, 2012b; HSE, 2013c; Samant et al., 2006; & OHS \\
\hline & Safety sheet (description of the machinery) & The sheet contains a description of the machinery and how it works and draws attention to aspects on how to use it safely. & UEA, 2007 & $\mathrm{OHS}$ \\
\hline & Criteria for design or purchasing & Set safety requirement related to the purchase/design of a new machinery & Hale et al., 2010 & OEE \\
\hline & Emergency buttons & Equip the machinery with safety buttons or change their position so that they are more easily reachable. & HSE, 2013c; Samant et al., 2006 & OHS \\
\hline
\end{tabular}




\begin{tabular}{|c|c|c|c|c|}
\hline & Replacement of the machinery & Substitution of a not safe machinery & & OEE \\
\hline PPE & PPE & Provide the adequate PPE to workers with reference to the tasks they have to perform. & $\begin{array}{l}\text { Barbeau et al., 2004; Cagno et al., 2014; Hale et al., 2010; } \\
\text { HSE, 2013b; Novartis, } 2014\end{array}$ & OHS \\
\hline \multirow[t]{3}{*}{ Noise } & Barriers against noise & Using screens, barriers, enclosures and absorbent materials to reduce the noise on its path to the people exposed & EASHW, 2003; HSE, 2012a; NYCOSH, 2014 & OHS \\
\hline & Lay out changes & (Re)designing and laying out the workplace to create quiet workstations) & EASHW, 2003; HSE 2012a.; NYCOSH, 2014 & OEE \\
\hline & Change machinery & Substitution of machinery with another less noisy (low noise purchasing policy) & EASHW, 2003; HSE, 2012a; NYCOSH, 2014 & OEE \\
\hline Set policies & Written policy & $\begin{array}{l}\text { The policy identifies hazards and assessing risks, deciding what precautions are needed. Health and safety policy should } \\
\text { influence all activities, including the } \\
\text { selection of people, equipment and materials, the way work is done }\end{array}$ & ACCI, 2004; Gardner et al., 1999; HSE, 2013a & OHS \\
\hline \multirow[t]{2}{*}{ Set standards } & Level of emission & Specifying levels of emissions that are accepted & HSE, 2013a & $\mathrm{OHS}+\mathrm{EE}$ \\
\hline & Level of waste & Specifying level of waste that is acceptable & HSE, 2013a & $\mathrm{OHS}+\mathrm{EE}$ \\
\hline Performance & Measures of performance & $\begin{array}{l}\text { It is necessary to evaluate performances in order to understand where the firm is compared to where it would like to be. } \\
\text { Evaluate the performance in a particular way at set time. The performance can be evaluated against the setting standards }\end{array}$ & HSE, 2013a & OEE \\
\hline \multirow[t]{3}{*}{ Safety record } & Checklist & $\begin{array}{l}\text { Make use of checklist as an operational tool to simplify and make it faster for the organization to verify the level of } \\
\text { compliance with legal regulations but also with its possible internal policies of its system of prevention and protection }\end{array}$ & ACCI, 2004; HSE, 2013a; Novartis, 2014 & OHS \\
\hline & Hazards/accidents record & Keep a record of accidents that have occurred in the firm and of the hazardous present & $\begin{array}{l}\text { ACCI, 2004; Barbeau et al, 2004; Gardner et al., 1999; HSE, } \\
\text { 2013a; Novartis, } 2014\end{array}$ & OHS \\
\hline & Hazardous substances register & $\begin{array}{l}\text { Keep a record of all the toxic or dangerous substances used by the firm for its processes with their relative potential effect on } \\
\text { environment and human being }\end{array}$ & $\begin{array}{l}\text { ACC, 2004; Barbeau et al, 2004; Gardner et al., 1999; HSE, } \\
\text { 2013a; Novartis, } 2014\end{array}$ & $\mathrm{OHS}+\mathrm{EE}$ \\
\hline Material & Replace toxic/dangerous material & Substitution of toxic and/or dangerous material both for environment and human being with a less or not toxic/dangerous one. & NYCOSH, 2014 & $\mathrm{OHS}+\mathrm{EE}$ \\
\hline \multirow{2}{*}{$\begin{array}{l}\text { Air quality } \\
\text { improvement }\end{array}$} & Customized air ventilation system & Considering different aspects of the workplace when designing a ventilation system in order to choose the best one & Calabrese, 2011 & $\mathrm{OHS}+\mathrm{EE}$ \\
\hline & Air ventilation system near workstation & Localized distribution: ventilation system's input near workplace & Calabrese, 2011 & OEE \\
\hline \multirow[t]{3}{*}{ Reduction of use } & $\begin{array}{l}\text { Change product specificition to use a different raw } \\
\text { or recycled raw material (no dangerous) }\end{array}$ & Modification of product specification in order to use a different material both raw or recycled & IAC, 2007 & EE \\
\hline & 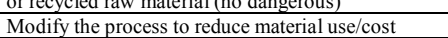 & Modification of process in order to reduce the use of material (reducing also the cost of it) & $\mathrm{IAC}, 2007$ & $\mathrm{EE}$ \\
\hline & Modify the process to reduce the use of water & Modification of process in order to reduce the use of water. & IAC, 2007 & $\frac{\mathrm{LL}}{\mathrm{EE}}$ \\
\hline $\begin{array}{l}\text { Reduction of } \\
\text { emission }\end{array}$ & Pollution/contaminants reduction & $\begin{array}{l}\text { Reduction of the contaminantst the firm release in the environment and reduction of emission of substances that make land, } \\
\text { water, air, etc., dirty and not safe or suitable to use }\end{array}$ & Gimenez et al., 2012; Pagell and Gobeli, 2009 & OEE \\
\hline
\end{tabular}




\section{References}

Abdelaziz, E.A., Saidur, R., Mekhilef, S., 2011. A review on energy saving strategies in industrial sector. Renew. Sustain. Energy Rev. 15, 150-168. doi:10.1016/j.rser.2010.09.003

ACCI, 2004. Small Business Safety Solution. Australian Chamber of Commerce and Industry. Retrieved from the WWW, December 2014: http://www.acci.asn.au/

Ambec, S., Lanoie, P., 2008. Does it pay to be green? A systematic overview. Acad. Manag. Perspect. 22, 45-62. doi:10.5465/AMP.2008.35590353

Anderson, S.T., Newell, R.G., 2004. Information programs for technology adoption: the case of energy-efficiency audits. Resour. Energy Econ. 26, 27-50. doi:10.1016/j.reseneeco.2003.07.001

Apeaning, R.W., Thollander, P., 2013. Barriers to and driving forces for industrial energy efficiency improvements in African industries - a case study of Ghana's largest industrial area. J. Clean. Prod. 53, 204-213. doi:10.1016/j.jclepro.2013.04.003

Arevalo, J.A., Aravind, D., 2011. Corporate social responsibility practices in India: approach, drivers, and barriers. Corp. Gov. 11, 399-414. doi:10.1108/14720701111159244

Barbeau, E., Roelofs, C., Youngstrom, R., Sorensen, G., Stoddard, A., LaMontagne, A.D., 2004. Assessment of occupational safety and health programs in small businesses. Am. J. Ind. Med. 45, 371-9. doi:10.1002/ajim.10336

Beckmann, M., Hielscher, S., Pies, I., 2014. Commitment strategies for sustainability: how business firms can transform trade-offs into win-win outcomes. Bus. Strateg. Environ. 23, 18-37. doi:10.1002/bse. 1758

Belal, A.R., Owen, D.L., 2007. The views of corporate managers on the current state of, and future prospects for, social reporting in Bangladesh: An engagement-based study. Accounting, Audit. Account. 20, 472-494. doi:10.1108/MRR-09-2015-0216

Bianchi, R., Noci, G., 1998. “ Greening ” SMEs ’ competitiveness. Small Bus. Econ. 11, 269-281.

Biondi, V., Frey, M., Iraldo, F., 1998. Environmental management system implementation by SMEs : EU experience and perspectives, in: Partnership and Leadership: Building Alliances for a Sustainable Future. Rome.

Blass, V., Corbett, C.J., Delmas, M.A., Muthulingam, S., 2014. Top management and the adoption of energy efficiency practices: Evidence from small and medium-sized manufacturing firms in the US. Energy 65, 560-571. doi:10.1016/j.energy.2013.11.030

Blok, V., Long, T.B., Gaziulusoy, A.I., Ciliz, N., Lozano, R., Huisingh, D., Csutora, M., Boks, C., 2015. From best practices to bridges for a more sustainable future: Advances and challenges in the transition to global sustainable production and consumption: Introduction to the ERSCP stream of the Special volume. J. Clean. Prod. 108, 19-30. doi:10.1016/j.jclepro.2015.04.119

Boyce, P.R., Veitch, J.A., Newsham, G.R., Jones, C.C., Heerwagen, J., Myer, M., Hunter, C.M., 2006. Occupant use of switching and dimming controls in offices. Light. Res. Technol. 38, 358376. doi:10.1177/1477153506070994

Brunke, J.C., Johansson, M., Thollander, P., 2014. Empirical investigation of barriers and drivers to the adoption of energy conservation measures, energy management practices and energy services in the Swedish iron and steel industry. J. Clean. Prod. 84, 509-525. doi:10.1016/j.jclepro.2014.04.078

CAC, 2003. Improving Compressed Air System Performance a sourcebook for industry. Compressed Air Challenge. sourcebook for industry. Retrieved from the WWW, December 2014: https://www.compressedairchallenge.org/library/\#Sourcebook. 
CAC, 1998a. Pressure Drop and Controlling System Pressure. Compressed Air Challenge. Retrieved from the WWW, 2014: https://www.compressedairchallenge.org/library/factsheets/factsheet07.pdf.

CAC, 1998b. Compressed Air System Leaks. Compressed Air Challenge. Retrieved from the WWW, December 2014: https://www.compressedairchallenge.org/library/factsheets/factsheet04.pdf.

Cagno, E., Masi, D., Leão, C.P., 2016. Drivers for OSH interventions in small and medium-sized enterprises. Int. J. Occup. Saf. Ergon. 22, 102-115. doi:10.1080/10803548.2015.1117351

Cagno, E., Micheli, G.J.L., Jacinto, C., Masi, D., 2014. An interpretive model of occupational safety performance for Small- and Medium-sized Enterprises. Int. J. Ind. Ergon. 44, 60-74. doi:10.1016/j.ergon.2013.08.005

Cagno, E., Trianni, A., 2012. Analysis of the most effective energy efficiency opportunities in manufacturing primary metals, plastics, and textiles small- and medium-sized enterprises. J. Energy Resour. Technol. 134, 21005. doi:10.1115/1.4006043

Cagno, E., Trianni, A., 2014. Evaluating the barriers to specific industrial energy efficiency measures: an exploratory study in small and medium-sized enterprises. J. Clean. Prod. 82, 70-83. doi:10.1016/j.jclepro.2014.06.057

Cagno, E., Worrell, E., Trianni, A., Pugliese, G., 2013. A novel approach for barriers to industrial energy efficiency. Renew. Sustain. Energy Rev. 19, 290-308. doi:10.1016/j.rser.2012.11.007

Calabrese, A., 2011. Gestione degli Impianti Industriali, 1st ed. CUSL, Milano.

Carbon Trust, 2011a. Motors and drives Introducing energy saving opportunities for business. Retrieved from the WWW, December 2014: www.carbontrust.com.

Carbon Trust, 2011b. Energy surveys A practical guide to identifying energy saving opportunities. Retrieved from the WWW, December 2014: www.carbontrust.com.

Carbon Trust, 2011c. Heating, ventilation and air conditioning Saving energy without compromising comfort. Retrieved from the WWW, December 2014: www.carbontrust.com.

Catarino, J., Henriques, J., Egreja, F., 2015. Portuguese SME toward energy efficiency improvement. Energy Effic. 8, 995-1013. doi:10.1007/s12053-015-9325-7

Champoux, D., Brun, J., 2003. Occupational health and safety management in small size enterprises : an overview of the situation and avenues for intervention and research. Saf. Sci. 41, 301-318. doi:10.1016/S0925-7535(02)00043-7

Chan, E.S.W., 2008. Barriers to EMS in the hotel industry. Int. J. Hosp. Manag. 27, 187-196. doi:10.1016/j.ijhm.2007.07.011

Cherniack, M., Lahiri, S., 2010. Barriers to implementation of workplace health interventions: an economic perspective. J. Occup. Environ. Med. 52, 934-942. doi:10.1097/JOM.0b013e3181f26e59

Chowdhury, M.M.H., Hossain, M.M., Dewan, M.N.A., 2015. A framework for selecting optimal strategies to mitigate the corporate sustainability barriers. Corp. Ownersh. Control 13, 462-481.

Collins, E., Roper, J., Lawrence, S., 2010. Sustainability Practices: Trends in New Zealand Businesses. Bus. Strateg. Environ. 19, 479-494. doi:10.1002/bse.653

Cooremans, C., 2012. Investment in energy efficiency: do the characteristics of investments matter? Energy Effic. 5, 497-518. doi:10.1007/s12053-012-9154-x

Côté, R., Booth, A., Louis, B., 2006. Eco-efficiency and SMEs in Nova Scotia, Canada. J. Clean. Prod. 14, 542-550. doi:10.1016/j.jclepro.2005.07.004

Cunningham, T.R., Sinclair, R., 2015. Application of a model for delivering occupational safety and 
health to smaller businesses: Case studies from the US. Saf. Sci. 71, 213-225. doi:10.1016/j.ssci.2014.06.011

Daddi, T., Giacomo, M.R. De, Dils, E., Polders, C., Rodrí, G., 2013. Transferring the Integrated Pollution Prevention and Control (IPPC) approach and Best Available Techniques (BAT) concepts to Egypt, Tunisia and Morocco. Sustainability 5, 2944-2959. doi:10.3390/su5072944

De Almeida, A.T., Ferreira, F.J.T.E., Both, D., 2005. Technical and economical considerations in the application of variable-speed drives With electric motor systems. IEEE Trans. Idustry Appl. 41, 188-199. doi:10.1109/ICPS.2004.1314992

De Almeida, A.T., Fonseca, P., Falkner, H., Bertoldi, P., 2003. Market transformation of energyefficient motor technologies in the EU. Energy Policy 31, 563-575. doi:10.1016/S03014215(02)00100-3

De Almeida, A.T., Greenberg, S., 1995. Technology assessment: energy-efficient belt transmissions. Energy Build. 22, 245-253. doi:10.1016/0378-7788(95)00926-O

De Groot, H.L. f., Verhoef, E.T., Nijkamp, P., 2001. Energy saving by firms: decision-making, barriers and policies. Energy Econ. 23, 717-740. doi:10.1016/S0140-9883(01)00083-4

De Paiva Duarte, F., 2015. Barriers to sustainability: an exploratory study on perspectives from Brazilian organizations. Sustain. Dev. 23, 425-434. doi:10.1002/sd.1603

Dicicco-Bloom, B., Crabtree, B.F., 2006. The qualitative research interview. Med. Educ. 40, 314-21. doi:10.1111/j.1365-2929.2006.02418.x

Dieleman, H., 2007. Cleaner Production and innovation theory. Social experiments as a new mdel to engage in cleaner production. Rev. Int. Contam. Ambient. 23, 79-94.

Dobes, V., 2013. New tool for promotion of energy management and cleaner production on no cure, no pay basis. J. Clean. Prod. 39, 255-264. doi:10.1016/j.jclepro.2012.08.007

Doniec, A., Reichel, J., Bulin, M., 2002. Assessment of the potential of cleaner production implementation in Polish enterprises. J. Clean. Prod. 10, 299-304. doi:10.1016/S09596526(01)00041-5

Doppelt, B., 2003. Overcoming the seven sustainability blunders. Syst. Thinker 14, 2-6.

Dyllick, T., Hockerts, K., 2002. Beyond the business case for corporate sustainability. Bus. Strateg. Environ. 11, 130-141. doi:10.1002/bse.323

EASHW, 2010. European Survey of Enterprises on New and Emerging Risks Managing safety and health at work. European Agency for Safety and Health at Work. Retrieved from the WWW, December 2014: https://osha.europa.eu/en/publications/reports/esener1_osh_management

EASHW, 2003. Improving occupational safety and health in SMEs : examples of effective assistance. European Agency for Safety and Health at Work. Retrieved from the WWW, December 2014: https://osha.europa.eu/en/publications/factsheets/37/view

Eisenhardt, K.M., 1989. Building Theories from Case Study Research. Acad. Manag. J. 14, 532-550. doi:10.5465/AMR.1989.4308385

Elkington, J., 1998. Accounting for the triple bottom line. Meas. Bus. Excell. 2, 18-22. doi:10.1108/eb025539

Eurostat, 2016. Manufacturing statistics. Retrieved from the WWW, March 2017: http://ec.europa.eu/eurostat/statistics-explained/index.php/Manufacturing_statistics_NACE_Rev._2

Evans, S., Bergendahl, M., Gregory, M., Ryan, C., 2009. Towards a sustainable industrial system. The Institute for Manufacturing, Cardiff. Retrieved from the WWW, March 2017: http://orbit.dtu.dk/fedora/objects/orbit:81752/datastreams/file_4085316/content 
Fennema, O., 2000. Industrial sustainability: Lifting the siege on earth and our descendents. Food Technol. 54.

Ferreira, F.J.T.E., Member, S., Fong, J.A.C., Almeida, A.T. De, 2011. Ecoanalysis of variable-speed drives for flow regulation in pumping systems 58, 2117-2125. doi:10.1109/TIE.2010.2057232

Fernández-Viñé, M.B., Gómez-Navarro, T., Capuz-Rizo, S.F., 2013. Assessment of the public administration tools for the improvement of the eco-efficiency of Small and Medium Sized Enterprises. J. Clean. Prod. 47, 265-273. doi:10.1016/j.jclepro.2012.08.026

Fernández-Viñé, M.B., Gómez-Navarro, T., Capuz-Rizo, S.F., 2010. Eco-efficiency in the SMEs of Venezuela. Current status and future perspectives. J. Clean. Prod. 18, 736-746. doi:10.1016/j.jclepro.2009.12.005

Fleiter, T., Hirzel, S., Worrell, E., 2012a. The characteristics of energy-efficiency measures - a neglected dimension. Energy Policy 51, 502-513. doi:10.1016/j.enpol.2012.08.054

Fleiter, T., Schleich, J., Ravivanpong, P., 2012b. Adoption of energy-efficiency measures in SMEsAn empirical analysis based on energy audit data from Germany. Energy Policy 51, 863-875. doi:10.1016/j.enpol.2012.09.041

Frankental, P., 2001. Corporate social responsibility - a PR invention? Corp. Commun. An Int. J. 6, 18-23. doi:10.1108/13563280110381170

Furlanetto, L., Garetti, M., Macchi, M., 2006. Principi generali di gestione della manutenzione, 1st ed. Franco Angeli, Milano.

Gaglia, A.G., Balaras, C. a., Mirasgedis, S., Georgopoulou, E., Sarafidis, Y., Lalas, D.P., 2007. Empirical assessment of the Hellenic non-residential building stock, energy consumption, emissions and potential energy savings. Energy Convers. Manag. 48, 1160-1175. doi:10.1016/j.enconman.2006.10.008

Gardner, D., Carlopio, J., Fonteyn, P.N., Cross, J.A., 1999. Mechanical equipment injuries in small manufacturing businesses . Knowledge, behavioral, and management issues. Int. J. Occup. Saf. Ergon. 5, 59-71. doi:10.1080/10803548.1999.11076411

Garetti, M., Taisch, M., 2012. Sustainable manufacturing: trends and research challenges. Prod. Plan. Control 23, 83-104. doi:10.1080/09537287.2011.591619

Gimenez, C., Sierra, V., Rodon, J., 2012. Sustainable operations: their impact on the triple bottom line. Int. J. Prod. Econ. 140, 149-159. doi:10.1016/j.ijpe.2012.01.035

Glavič, P., Lukman, R., 2007. Review of sustainability terms and their definitions. J. Clean. Prod. 15, 1875-1885. doi:10.1016/j.jclepro.2006.12.006

Gombault, M., Versteege, S., 1999. Cleaner production in SMEs through a partnership with ( local ) authorities: successes from the Netherlands. J. Clean. Prod. 7, 249-261. doi:10.1016/S09596526(99)00084-0

Gunningham, N., Sinclair, D., 1997. ACEL Final Report: Barriers and Motivators to the Adoption of Cleaner Production Practices. Australian Centre for Environment Law, Canberra, Australia.

Haffar, M., Searcy, C., 2017. Classification of Trade-offs Encountered in the Practice of Corporate Sustainability. J. Bus. Ethics 140, 1-28. doi:10.1007/s10551-015-2678-1

Hale, A.R., Guldenmund, F.W., Van Loenhout, P.L.C.H., Oh, J.I.H., 2010. Evaluating safety management and culture interventions to improve safety: Effective intervention strategies. Saf. Sci. 48, 1026-1035. doi:10.1016/j.ssci.2009.05.006

Hami, N., Razali, M., Ebrahim, Z., Norsiah, H., Mohd Razali, M., Zuhriah, E., 2015. The Impact of Sustainable Manufacturing Practices and Innovation Performance on Economic Sustainability, Procedia CIRP. Elsevier B.V. doi:10.1016/j.procir.2014.07.167 
Harris, J., Anderson, J., Shafron, W., 2000. Investment in energy efficiency : a survey of Australian firms. Energy Policy 28, 867-876. doi:10.1016/S0301-4215(00)00075-6

Hasanbeigi, A., Menke, C., Du Pont, P., 2010. Barriers to energy efficiency improvement and decision-making behavior in Thai industry. Energy Effic. 3, 33-52. doi:10.1007/s12053-0099056-8

Hasle, P., Limborg, H.J., 2006. A review of the literature on preventive occupational health and safety activities in small enterprises. Ind. Health 44, 6-12. doi:10.2486/indhealth.44.6

Henri, J.-F., Journeault, M., 2009. Eco-efficiency and organizational practices: an exploratory study of manufacturing firms. Environ. Plan. C Gov. Policy 27, 894-921. doi:10.1068/c0827

Hillary, R., 2004. Environmental management systems and the smaller enterprise. J. Clean. Prod. 12, 561-569. doi:10.1016/j.jclepro.2003.08.006

Hillebrand, B., Kok, R.A.W., Biemans, W.G., 2001. Theory-testing using case studies. Ind. Mark. Manag. 30, 651-657. doi:10.1016/S0019-8501(00)00115-2

Hossain, M.M., Rowe, A.L., Quaddus, M., 2010. Drivers and barriers of corporate social and environmental reporting (CSER) practices in a developing country : Evidence from Bangladesh, in: 10th Interdisciplinary Perspectives on Accounting Conference. Cardiff.

HSE, 2013a. Providing and using work equipment safely A brief guide. Health and Safety Executive. Retrieved from the WWW, December 2014: www.hse.gov.uk/pubns/indg275.pdf.

HSE, 2013b. Managing Health and Safety: Five Steps to Success. Health and Safety Executive. Retrieved from the WWW, December 2014: www.hse.gov.uk/pubns/indg174.pdf.

HSE, 2013c. Personal protective equipment (PPE) at work. Health and Safety Executive. Retrieved from the WWW, December 2014: http://www.hse.gov.uk/pubns/indg291.htm.

HSE, 2012a. Using work equipment safely. Health and Safety Executive. Retrieved from the WWW, December 2014: http://www.hse.gov.uk/pubns/indg362.

HSE, 2012b. Noise at work A brief guide to controlling the risk. Health and Safety Executive. Retrieved from the WWW, December 2014: http://www.hse.gov.uk/pubns/indg229.htm.

ILO, 2011. XIX World Congress on Safety and Health at Work : ILO Introductory Report: Global Trends and Challenges on Occupational Safety and Health. Geneva. Retrieved from the WWW, December 2014: <http://www.ilo.org/safework/info/publications/WCMS_162662/lang-en/index.htm>

INAIL, 2014. Banche Dati. http://bancadaticsa.inail.it/bancadaticsa/login.asp (accessed 10.31.15)

Jones, C.C., Richman, E., 2005. Lighting Business Case A Reporting Analyzing Lighting Technology Opportunities with High Return on Investment Energy Savings for the Federal Sector. Richland, Washington.

Klewitz, J., Hansen, E.G., 2014. Sustainability-oriented innovation of SMEs: A systematic review. J. Clean. Prod. 65, 57-75. doi:10.1016/j.jclepro.2013.07.017

Kostka, G., Moslener, U., Andreas, J., 2013. Barriers to increasing energy efficiency: evidence from small-and medium-sized enterprises in China. J. Clean. Prod. 57, 59-68. doi:10.1016/j.jclepro.2013.06.025

Lamm, F., 1999. Occupational health \& safety in Australian small business : what can be done to reduce the lack of awareness and raise the level of compliance in Australian small business? Industrial Relations Research Centre, University of New South Wales, Sidney.

Li, D.H.W., Cheung, K.L., Wong, S.L., Lam, T.N.T., 2010. An analysis of energy-efficient light fittings and lighting controls. Appl. Energy 87, 558-567. doi:10.1016/j.apenergy.2009.07.002 
Liu, X., Yamamoto, R., Suk, S., 2014. A survey of company's awareness and approval of marketbased instruments for energy saving in Japan. J. Clean. Prod. 78, 35-47. doi:10.1016/j.jclepro.2014.05.005

Lo, S., Sheu, H., 2007. Is corporate sustainability a value-increasing strategy for business? Corp. Gov. An Int. Rev. 15, 345-358. doi:10.1111/j.1467-8683.2007.00565.x

Lodhia, S.K., 2003. Accountants' responses to the environmental agenda in a developing nation: An initial and exploratory study on Fiji. Crit. Perspect. Account. 14, 715-737. doi:10.1016/S10452354(02)00190-9

Lozano, R., 2013. Are companies planning their organisational changes for corporate sustainability? An analysis of three case studies on resistance to change and their strategies to overcome it. Corp. Soc. Responsib. Environ. Manag. 20, 275-295. doi:10.1002/csr.1290

Lozano, R., Carpenter, A., Huisingh, D., 2015. A review of "theories of the firm" and their contributions to Corporate Sustainability. J. Clean. Prod. 106, 430-442. doi:10.1016/j.jclepro.2014.05.007

Mahlia, T.M.I., Razak, H.A., Nursahida, M. a., 2011. Life cycle cost analysis and payback period of lighting retrofit at the University of Malaya. Renew. Sustain. Energy Rev. 15, 1125-1132. doi:10.1016/j.rser.2010.10.014

Manzan, R., Miyake, D.I., 2013. A study on alternative approaches to instill environmental concerns in the domain of production management of industrial firms. J. Technol. Manag. Innov. 8, 198207. doi:10.4067/S0718-27242013000400018

Martín-Peña, M.L., Díaz-Garrido, E., Sánchez-López, J.M., 2014. Analysis of benefits and difficulties associated with firms' Environmental Management Systems: the case of the Spanish automotive industry. J. Clean. Prod. 70, 220-230. doi:10.1016/j.jclepro.2014.01.085

Masi, D., Cagno, E., 2015. Barriers to OHS interventions in Small and Medium-sized Enterprises. Saf. Sci. 71, 226-241. doi:10.1016/j.ssci.2014.05.020

Masi, D., Cagno, E., Micheli, G.J.L., 2014. Developing , Implementing and Evaluating OSH Interventions in SMEs: an Exploratory Study. Int. J. Occup. Saf. Ergon. 20, 1-10. doi:10.1080/10803548.2014.11077059

Massoud, M.A., Fayad, R., El-Fadel, M., Kamleh, R., 2010. Drivers, barriers and incentives to implementing environmental management systems in the food industry: A case of Lebanon. J. Clean. Prod. 18, 200-209. doi:10.1016/j.jclepro.2009.09.022

Matus, K.J.M., Xiao, X., Zimmerman, J.B., 2012. Green chemistry and green engineering in China: drivers, policies and barriers to innovation. J. Clean. Prod. 32, 193-203. doi:10.1016/j.jclepro.2012.03.033

Maximiano, J.M.B., 2005. The state of corporate social responsibility in the Philippines. Aust. Assoc. Prof. Appl. Ethics 12th Annu. Conf. 1-18.

Melikov, A.K., 2004. Personalized ventilation. Indoor Air 14, 157-67. doi:10.1111/j.16000668.2004.00284.x

Mellor, N., Mackay, C., Packham, C., Jones, R., Palferman, D., Webster, S., Kelly, P., 2011. "Management Standards" and work-related stress in Great Britain: Progress on their implementation. Saf. Sci. 49, 1040-1046. doi:10.1016/j.ssci.2011.01.010

Meredith, J., 1998. Building operations management theory through case and field research. J. Oper. Manag. 16, 441-454. doi:10.1108/01443579310048182

Micheli, G., Cagno, E., 2008. Percezione delle problematiche della sicurezza ed investimenti in gestione della sicurezza nelle piccole e medie imprese: Indagine sul territorio di Lecco. Prev. 


\section{Oggi 4, 7-24.}

Ministerie Van Vrom, 2004. Clean , clever and competitive. Knowledge document. Retrieved from the WWW, December 2014: http://mvoplatform.nl/publications-en/Publication_1321.

Mittal, V.K., Egede, P., Herrmann, C., Sangwan, K.S., 2013. Comparison of drivers and barriers to green manufacturing: a case of India and Germany, in: Re-Engineering Manufacturing for Sustainability. Springer Singapore, pp. 723-728. doi:10.1007/978-981-4451-48-2_118

Mittal, V.K., Sangwan, K.S., 2014. Prioritizing barriers to green manufacturing: environmental, eocial and economic perspectives. Procedia CIRP 17, 559-564. doi:10.1016/j.procir.2014.01.075

Moors, E.H.M., Mulder, K.F., Vergragt, P.J., 2005. Towards cleaner production: barriers and strategies in the base metals producing industry. J. Clean. Prod. 13, 657-668. doi:10.1016/j.jclepro.2003.12.010

IAC, 2007. The ARC Manual 9.1. Industrial Assessment Centre. Retrieved from the WWW, July 2017: https://iac.university/technicalDocs/ARC_list_9.1.pdf

Murillo-Luna, J.L., Garcés-Ayerbe, C., Rivera-Torres, P., 2011. Barriers to the adoption of proactive environmental strategies. J. Clean. Prod. 19, 1417-1425. doi:10.1016/j.jclepro.2011.05.005

Naeem, M.A., Welford, R., 2009. A comparative study of corporate social responsibility in Bangladesh and Pakistan. Corp. Soc. Responsib. Environ. Manag. 16, 108-122. doi:10.1002/csr.185

Nagesha, N., Balachandra, P., 2006. Barriers to energy efficiency in small industry clusters: multicriteria-based prioritization using the analytic hierarchy process. Energy 31, 1969-1983. doi:10.1016/j.energy.2005.07.002

Novartis, 2014. Health, Safety and Environment Policy Novartis Global Policy. Retrieved from the WWW, December 2014: http://www.novartis.com/corporateresponsibility/resources/index.shtml.

NYCOSH, 2014. Hierarchy of Hazard Controls New York Committee for Occupational Safety and Health. Retrieved from the WWW, December 2014: URL http://nycosh.org/index.php?page=Hierarchy-of-Hazard-Controls.

Okazaki, T., Yamaguchi, M., 2011. Accelerating the transfer and diffusion of energy saving technologies steel sector experience-Lessons learned. Energy Policy 39, 1296-1304. doi:10.1016/j.enpol.2010.12.001

Pagell, M., Gobeli, D., 2009. How plant managers' experiences and attitudes toward sustainability relate to operational performance. Prod. Oper. Manag. 18, 278-299. doi:10.1111/j.19375956.2009.01050.x

Pagell, M., Wu, Z.H., 2009. Building a more complete theory of sustainable supply chain management using case studies of 10 exemplars. J. Supply Chain Manag. 45, 37-56. doi:10.1111/j.1745-493X.2009.03162.x

Paramanathan, S., Farrukh, C., Phaal, R., Probert, D., 2004. Implementing industrial sustainability: the research issues in technology management. R\&D Manag. 34, 527-537. doi:10.1111/j.14679310.2004.00360.x

Patton, M. Q. 1990, Qualitative Evaluation Methods. SAGE, Beverly Hills.

Pehlken, A., Decker, A., Kottowski, C., Kirchner, A., Thoben, K.D., 2015. Energy efficiency in processing of natural raw materials under consideration of uncertainties. J. Clean. Prod. 106, 351-363. doi:10.1016/j.jclepro.2014.08.076

Quinlan, M., Mayhew, C., 2000. Precarious Employment, Work Re-Organisation and the Fracturing 
of OHS Management, in: Systematic OHS Management: Perspectives on an International Development. Elsevier, Amsterdam.

Rademaekers, K., Zaki, S.S., Smith, M., 2011. Sustainable Industry: going for growth \& Resource Efficiency. Retrieved from the WWW, March 2016: http://www.symbiosis.dk/en/content/sustainable-industry-going-growth-resource-efficiency

Reddy, B.S., 2013. Barriers and drivers to energy efficiency - A new taxonomical approach. Energy Convers. Manag. 74, 403-416. doi:10.1016/j.enconman.2013.06.040

Reddy, B.S., Shrestha, R.M., 1998. Barriers to the adoption of efficient electricity technologies: a case study of India. Int. J. Energy Res. 22, 257-270. doi:10.1002/(SICI)1099114X(19980310)22:3<257::AID-ER358>3.0.CO;2-C

Rohdin, P., Thollander, P., 2006. Barriers to and driving forces for energy efficiency in the nonenergy intensive manufacturing industry in Sweden. Energy 31, 1836-1844. doi:10.1016/j.energy.2005.10.010

Rohdin, P., Thollander, P., Solding, P., 2007. Barriers to and drivers for energy efficiency in the Swedish foundry industry. Energy Policy 35, 672-677. doi:10.1016/j.enpol.2006.01.010

Rubenowitz, S., 1997. Survey and intervention of ergonomic problems at the workplace. Int. J. Ind. Ergon. 19, 271-275. doi:10.1016/S0169-8141(96)00036-4

Saidur, R., Mekhilef, S., Ali, M.B., Safari, A., Mohammed, H.A., 2012. Applications of variable speed drive (VSD) in electrical motors energy savings. Renew. Sustain. Energy Rev. 16, 543550. doi:10.1016/j.rser.2011.08.020

Salzmann, O., Ionescu-Somers, A.M., Steger, U., 2005. The business case for corporate sustainability: literature review and research options. Eur. Manag. J. 23, 27-36. doi:10.1016/j.emj.2004.12.007

Samant, Y., Parker, D., Brosseau, L., Pan, W., Xi, M., Haugan, D., 2006. Profile of machine safety in small metal fabrication businesses. Am. J. Ind. Med. 49, 352-9. doi:10.1002/ajim.20294

Sardianou, E., 2008. Barriers to industrial energy efficiency investments in Greece. J. Clean. Prod. 16, 1416-1423. doi:10.1016/j.jclepro.2007.08.002

Schleich, J., 2009. Barriers to energy efficiency: a comparison across the German commercial and services sector. Ecol. Econ. 68, 2150-2159. doi:10.1016/j.ecolecon.2009.02.008

Schleich, J., Gruber, E., 2008. Beyond case studies: barriers to energy efficiency in commerce and the services sector. Energy Econ. 30, 449-464. doi:10.1016/j.eneco.2006.08.004

Setthasakko, W., 2009. Barriers to implementing corporate environmental responsibility in Thailand: a qualitative approach. Int. J. Organ. Anal. 17, 169-183. doi:10.1108/19348830910974905

Shi, H., Peng, S.Z., Liu, Y., Zhong, P., 2008. Barriers to the implementation of cleaner production in Chinese SMEs: government, industry and expert stakeholders' perspectives. J. Clean. Prod. 16, 842-852. doi:10.1016/j.jclepro.2007.05.002

Siaminwe, L., Chinsembu, K.C., Syakalima, M., 2005. Policy and operational constraints for the implementation of cleaner production in Zambia. J. Clean. Prod. 13, 1037-1047. doi:10.1016/j.jclepro.2004.12.005

Silva Lopes, A.D., Delai, I., De Castro, S.A.M., Roberto, A., 2013. Quality tools applied to Cleaner Production programs : a first approach toward a new methodology. J. Clean. Prod. 47, 174-187. doi:10.1016/j.jclepro.2012.10.026

Smith, M.J., Carayon, P., 2009. Using the 'Balance Model' for Occupational Safety and Health Promotion, in: Ergonomics and Health Aspects of Work with Computers. Springer, Verlag, Berlin, Heidelberg, pp. 105-114. doi:10.1007/978-3-642-02731-4_13 
Sorrell, S., Mallett, A., Nye, S., 2010. Barriers to Industrial Energy Efficiency: A Literature Review, Background Study for the UNIDO Industrial Development Report (IDR) 'Industrial Energy Efficiency Pays, Why Is It Not Happening?'. SPRU, University of Sussex. Retrieved from the WWW, July 2017:

http://sro.sussex.ac.uk/53957/1/WP102011_Barriers_to_Industrial_Energy_Efficiency__A_Literature_Review.pdf

Sorrell, S., O’Malley, E., Schleich, J., Scott, S., 2004. The Economics of Energy Efficiency. Edward Elgar Publishing, Cheltenham, UK.

Sorrell, S., Schleich, J., Scott, S., O’Malley, E., Trace, F., Boede, U., Ostertag, K., Radgen, P., 2000. Barriers to energy efficiency in public and private organizations, SPRU, Final Report.: http://www.sussex.ac.uk/Units/spru/publications/reports/barriers/final.html

Stuart, I., Mccutcheon, D., Handfield, R., Mclachlin, R., Samson, D., 2002. Effective case research in operations management: a process perspective. J. Oper. Manag. 20, 419-433. doi:10.1016/S0272-6963(02)00022-0

Studer, S., Welford, R., Hills, P., 2006. Engaging Hong Kong Businesses in Environmental Change : Drivers and Barriers. Bus. Strateg. Environ. 431, 416-431. doi:10.1002/bse.516

Tanzil, D., Beloff, B.R., 2006. Assessing impacts: overview on sustainability indicators and metrics. Environ. Qual. Manag. 15, 41-56. doi:10.1002/tqem.20101

Theberge, N., Neumann, W.P., 2010. Doing "organizational work": expanding the conception of professional practice in ergonomics. Appl. Ergon. 42, 76-84. doi:10.1016/j.apergo.2010.05.002

Thollander, P., Danestig, M., Rohdin, P., 2007. Energy policies for increased industrial energy efficiency: Evaluation of a local energy programme for manufacturing SMEs. Energy Policy 35, 5774-5783. doi:10.1016/j.enpol.2007.06.013

Thollander, P., Ottosson, M., 2008. An energy efficient Swedish pulp and paper industry - exploring barriers to and driving forces for cost-effective energy efficiency investments. Energy Effic. 1, 21-34. doi:10.1007/s12053-007-9001-7

Thollander, P., Palm, J., 2012. Efficiency in industrial energy systems: an interdisciplinary perspective on barriers, energy audits, energy management, policies, and programs. Springer, London.

Tompa, E., Dolinschi, R., De Oliveira, C., 2006. Practice and potential of economic evaluation of workplace-based interventions for occupational health and safety. J. Occup. Rehabil. 16, 375400. doi:10.1007/s10926-006-9035-2

Tonelli, F., Evans, S., Taticchi, P., 2013. Industrial sustainability : challenges, perspectives, actions. Int. J. Bus. Inov. Res. 7, 143-163. doi:10.1504/IJBIR.2013.052576

Trianni, A., Cagno, E., 2012. Dealing with barriers to energy efficiency and SMEs: Some empirical evidences. Energy 37, 494-504. doi:10.1016/j.energy.2011.11.005

Trianni, A., Cagno, E., De Donatis, A., 2014. A framework to characterize energy efficiency measures. Appl. Energy 118, 207-220. doi:10.1016/j.apenergy.2013.12.042

Trianni, A., Cagno, E., Thollander, P., Backlund, S., 2013a. Barriers to industrial energy efficiency in foundries: a European comparison. J. Clean. Prod. 40, 161-176. doi:10.1016/j.jclepro.2012.08.040

Trianni, A., Cagno, E., Worrell, E., 2013b. Innovation and adoption of energy efficient technologies: An exploratory analysis of Italian primary metal manufacturing SMEs. Energy Policy 61, 430 440. doi:10.1016/j.enpol.2013.06.034 
Trianni, A., Cagno, E., Worrell, E., Pugliese, G., 2013c. Empirical investigation of energy efficiency barriers in Italian manufacturing SMEs. Energy 49, 444-458. doi:10.1016/j.energy.2012.10.012

U.S Department of Energy, 2005. Energy Tips - Motor Systems. Retrieved from the WWW, December 2014: http://www.energy.gov/eere/amo/motor-systems.

U.S Department of Energy, 2002. Right-size heating and cooling equipment The correct size improves comfort and reduces costs, maintenance, and energy use. Retrieved from the WWW, December 2014: http://purl.access.gpo.gov/GPO/LPS106503

UEA Union Europeenne de l'Ameublement, 2007. Best practices to reduce the number of accidents in the furniture industry. Retrieved from the WWW, December 2014: http://www.ueanet.com/far/

Van Berkel, R., 2007. Eco-efficiency in primary metals production: Context, perspectives and methods. Resour. Conserv. Recycl. 51, 511-540. doi:10.1016/j.resconrec.2007.03.007

Van Der Byl, C.A., Slawinski, N., 2015. Embracing Tensions in Corporate Sustainability: A Review of Research From Win-Wins and Trade-Offs to Paradoxes and Beyond. Organ. Environ. 28, 5479. doi: $10.1177 / 1086026615575047$

Van Hemel, C., Cramer, J., 2002. Barriers and stimuli for ecodesign in SMEs. J. Clean. Prod. 10, 439-453. doi:10.1016/S0959-6526(02)00013-6

Van Marrewijk, M., 2003. Concepts and definitions of CSR and corporate sustainability: Between agency and communion. J. Bus. Ethics 44, 95-105. doi:10.2307/25075020

Venmans, F., 2014. Triggers and barriers to energy efficiency measures in the ceramic, cement and lime sectors. J. Clean. Prod. 69, 133-142. doi:10.1016/j.jclepro.2014.01.076

Vermeulen, W.J. V, Witjes, S., 2016. On addressing the dual and embedded nature of business and the route towards corporate sustainability. J. Clean. Prod. 112, 2822-2832. doi:10.1016/j.jclepro.2015.09.132

Vernon, J., Essex, S., Pinder, D., Curry, K., 2003. The "greening" of tourism micro-businesses: outcomes of focus group investigations in South East Cornwall. Bus. Strateg. Environ. 12, 4969. doi:10.1002/bse.348

Vieira, L.C., Amaral, F.G., 2015. Barriers and strategies applying cleaner production: a systematic review. J. Clean. Prod. 113, 5-16. doi:10.1016/j.jclepro.2015.11.034

Voss, C., Tsikriktsis, N., Frohlich, M., 2002. Case research in operations management. Int. J. Oper. Prod. Manag. 22, 195-219. doi:10.1108/01443570210414329

Walker, D., Tait, R., 2004. Health and safety management in small enterprises: an effective low cost approach. Saf. Sci. 42, 69-83. doi:10.1016/S0925-7535(02)00068-1

Walsh, C., Thornley, P., 2012. Barriers to improving energy efficiency within the process industry with a focus on low grade heat utilisation. J. Clean. Prod. 23, 138-146. doi:10.1016/j.jclepro.2011.10.038

WBCSD, UNEP, 1998. Cleaner Production and Eco-efficiency Complementary Approaches to Sustainable Development. Retrieved from the WWW, July 2017: http://gcpcenvis.nic.in/PDF/eco\%20effiency\%20and\%20CP.pdf

Weber, L., 1997. Some reflections on barriers to the efficient use of energy. Energy Policy 25, 833835. doi:10.1016/S0301-4215(97)00084-0

Whysall, Z., Haslam, C., Haslam, R., 2006. Implementing health and safety interventions in the workplace: An exploratory study. Int. J. Ind. Ergon. 36, 809-818. doi:10.1016/j.ergon.2006.06.007

Worrell, E., Price, L., 2001. Policy scenarios for energy efficiency improvement in industry. Energy 
Policy 29, 1223-1241. doi:10.1016/S0301-4215(01)00069-6

Yin, R.K., 2009. Case Study Research Design and Methods, 4th ed. SAGE, Thousand Oaks.

Zhang, B., Bi, J., Liu, B., 2009. Drivers and barriers to engage enterprises in environmental management initiatives in Suzhou Industrial Park, China. Front. Environ. Sci. Eng. China 3, 210-220. doi:10.1007/s11783-009-0014-7

Zilahy, G., 2004. Organisational factors determining the implementation of cleaner production measures in the corporate sector. J. Clean. Prod. 12, 311-319. doi:10.1016/S09596526(03)00016-7

Zorzini, M., Hendry, L., Stevenson, M., Pozzetti, A., 2008. Customer enquiry management and product customization An empirical multi-case study analysis in the Italian capital goods sector. Int. J. Oper. Prod. Manag. 28, 1186-1218. doi:10.1108/01443570810919369 